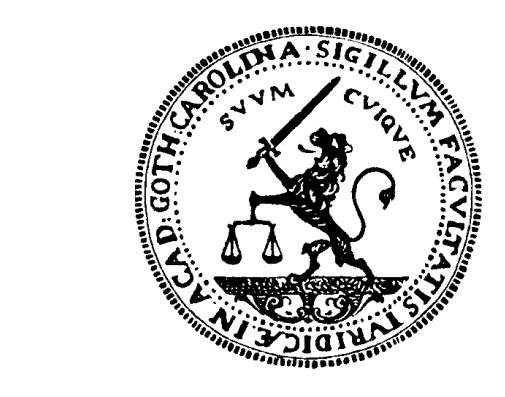

FACULTY OF LAW

Lund University

Kitti Jayangakula

\title{
Is the Doctrine of Joint Criminal Enterprise a Legitimate Mode of Individual Criminal Liability? - A Study of the Khmer Rouge Trials
}

\author{
Master thesis \\ 30 credits (30 ECTS)
}

Dr. Daniel Kuwali

Master Programme in International Human Rights Law 


\section{Contents}

$\begin{array}{ll}\text { SUMMARY } & 1\end{array}$

PREFACE 2

ABBREVIATIONS 3

1 INTRODUCTION 4

1.1 Background 4

$\begin{array}{lll}1.2 & \text { Purpose and Subject Matter } & 7\end{array}$

$\begin{array}{lll}1.3 & \text { Methodology and Materials } & 7\end{array}$

$\begin{array}{lll}1.4 & \text { Delimitation } & 8\end{array}$

$\begin{array}{lll}1.5 & \text { Disposition } & 8\end{array}$

2 FRAMING THE DOCTRINE OF JCE IN INTERNATIONAL CRIMINAL LAW 10

2.1 An Overview of the doctrine of JCE 10

2.2 The Origins and Development 11

2.2.1 Post-WWII Jurisprudence $\quad 12$

2.2.2 The ICTY Jurisprudence: Furundžija case and Tadić case 13

2.2.3 Post-Tadić Jurisprudence 15

$\begin{array}{lll}2.2 .3 .1 & \text { ICTY } & 15\end{array}$

2.2.3.2 The Jurisprudence of the ICTR as regards JCE 16

2.2.3.3 The Philosophy of the ICC on the doctrine of JCE 17

2.2.3.4 The reasoning of the SCSL vis-à-vis JCE 17

2.2.3.5 The doctrine of JCE in the ECCC 18

2.2.3.6 The Application of JCE in other Hybrid Courts 19

2.3 Categories of JCE 19

2.3.1 JCE I: The Basic Form 20

2.3.2 JCE II: The Systemic Form 20

2.3.3 JCE III: The Extended Form 21

2.4 Elements of JCE $\quad 21$

2.4.1 Subjective Elements (actus reus) 21

2.4.2 Objective Elements (mens rea) 23

2.5 Distingushing JCE Liability and Aiding and Abetting Liability 24

$2.6 \quad$ Rationale of JCE doctrine 25

2.7 What is the Legitimacy of the Application of JCE in International Criminal $\begin{array}{ll}\text { Proceedings? } & 27\end{array}$ 
2.8 The test of the Application of JCE in the Prosecution 28

2.8.1 The Development of the Principle of nullum crimen sine lege 29

2.8.2 Testing the Legality of the principle of nullum crimen sine lege 30

2.8.2.1 The Existence of the Law 31

2.8.2.2 Foreseeability and Accessibility Requirement 31

3 THE KHMER ROUGE TRIALS AND THE ECCC 34

3.1 Historical Background 34

3.2 The Khmer Rouge Trials before the ECCC 35

3.3 Jurisdiction of the ECCC 36

3.3.1 Ratione Temporis Jurisdiction $\quad 37$

3.3.2 Ratione Personae Jurisdiction $\quad 37$

3.3.3 Ratione Materiae Jurisdiction $\quad 38$

3.4 Individual Criminal Responsibility under ECCC Law 42

4 JCE APPLICABILITY AND THE ECCC 44

4.1 Procedural Background 44

4.2 The Application of JCE before the ECCC 46

4.2.1 The ECCC Legal Regime Condition 48

4.2.2 The Condition of Legality 50

4.2.2.1 The Existence of the Law Requirement 50

4.2.2.2 Foreseeability and Accessiblility Requirement 50

4.3 Analysis of the Legality of the Application of JCE Liability before the
ECCC

4.3.1 The Existence of the Law 51

4.3.1.1 Customary international law 51

4.3.1.2 National Cambodian Law 54

4.3.2 Foreseeability and Accessibility 55

4.4 Recent Jurisprudence of the ECCC on the Legality of the Application of $\begin{array}{ll}\text { JCE } & 58\end{array}$

4.5 Legitimacy of the Application of JCE Liability 59

4.5.1 Legitimacy and Values Balancing in International Criminal Proceedings 60

$\begin{array}{lll}\text { 4.5.1.1 Legal Values } & 61\end{array}$

4.5.1.2 Moral Values $\quad 62$

4.5.1.3 Political Values 63

4.5.2 Critique on Legitimacy: Case of Duch $\quad 64$

4.5.2.1 Facts of the case $\quad 64$

4.5.2.2 Analysis of the Legitimacy 65

5 CONCLUSION $\quad 67$ 
TABLE OF CASES 


\section{Summary}

The doctrine of joint criminal enterprise (JCE) is a form of individual criminal liability in international criminal law. This doctrine was formed by the Appeals Chamber of the ICTY in the Tadic Case in 1999. Since then, the JCE has grown to play a major role in the charges and convictions before international criminal tribunal. Due to this doctrine, the members who formed the criminal plan are responsible not only for those crimes they agreed to, but for all other crimes that would be considered the natural and foreseeable consequence of the plan regardless of whether those crimes were committed by person outside the criminal plan.

The JCE is accepted as one of the most important and effective tools in the prosecution, however, it also is one of the most difficult and controversial prosecutorial tools. The employment of JCE in the prosecution before the international criminal tribunals frequently faces the problem of the violation of the principle of nullum crimen sine lege. Similarly, before the Extraordinary Chambers in the Courts of Cambodia (ECCC), the application of JCE has become a problematic issue on the question regarding the legality; whether the application of JCE before the ECCC, for taking into account the crimes committed during 1975-1979, violates the principle of nullum crimen sine lege.

The JCE is considered as a mode of liability within the meaning of 'committing' in Article 29 of the ECCC Law, then the application of JCE before the ECCC is in the legal regime of the Court. However, the use of JCE must respect the principle of nullum crimen sine lege, which is the fundamental principle in international human rights law and international criminal law. Due to this, the application of this doctrine must satisfy the condition of legality, that is, the existence of the law requirement and foreseeability and accessibility requirement.

The main objective of this study is to analyse the legality and legitimacy of the application of JCE as at the ECCC, particularly in the case of Kiang Guek Eav alias Duch (Duch). The study shows that the application of the extended form of JCE (JCE III) before the ECCC would violate the principle of nullum crimen sine lege. However, to analyse the legitimacy, the ECCC must balance the values of the proceedings: legal, political and moral, which is based on a case-by-case basis.

The study on the Duch Case shows that even the application of JCE III would be illegal; however, the application of JCE before the ECCC against Duch is still legitimate. Hence, in the author's view, the doctrine of JCE may be a legitimate tool in the prosecution of Duch at the ECCC. 


\section{Preface}

At the first place, the author would like to thank everyone who has encouraged and helped me in the process of writing this thesis. Special thanks to my supervisor, Daniel Kuwali, for his suggestions, support and encouragement though this study. His comments and suggestions inspired me to write my thesis on this topic as well as motivated me to continue my writing through the completion.

Secondly, as a scholarship grantee, the author would like to express my gratitude to the Swedish International Development Cooperation Agency (SIDA) and the Raoul Wallenberg Institute for the great opportunity to come and to attend this Master Programme at Lund University in Sweden. Without this support, it is not easy for me to come and to complete my study here.

Finally, I would like to give my warmest thankfulness to all long-distance encouragement and support from my family and my friends in Thailand.

Kitti Jayangakula

Lund, Sweden

May 2010 


\section{Abbreviations}

$\begin{array}{ll}\text { CCL No. 10 } & \text { Control Council Law No. 10 } \\ \text { ECCC } & \text { Extraordinary Chambers in the Courts of } \\ & \text { Cambodia } \\ \text { ECCC Law } & \text { Law on the Establishment of the Extraordinary } \\ & \text { Chambers in the Courts of Cambodia for the } \\ & \text { Prosecution of Crimes Committed During the } \\ & \text { Period of Democratic Kampuchea } \\ \text { ECHR } & \text { European Convention on Human Right of 1950 } \\ \text { GA Res. } & \text { General Assembly Resolution } \\ \text { Genocide Convention } & \text { Convention on the Prevention and Punishment of } \\ & \text { Genocide of 1948 } \\ \text { ICC } & \text { International Criminal Court } \\ \text { ICCPR } & \text { International Covenant on Civil and Political } \\ & \text { Rights } \\ \text { ICJ } & \text { International Court of Justice } \\ \text { ICTR } & \text { International Criminal Tribunal for Rwanda } \\ \text { ICTY } & \text { International Criminal Tribunal for the Former } \\ & \text { Yugoslavia } \\ \text { IMT } & \text { International Military Tribunal } \\ \text { JCE } & \text { Joint Criminal Enterprise } \\ \text { Nuremberg Tribunal } & \text { International Military Tribunal at Nuremberg } \\ \text { OCIJ } & \text { Office of Co-Investigating Judges } \\ \text { OCP } & \text { Office of Co-Prosecutors } \\ \text { PTC } & \text { Pre-Trial Chamber } \\ \text { POW } & \text { Prisoner of War } \\ \text { SCSL } & \text { Special Court for Sierra Leone } \\ \text { SICT } & \text { Supreme Iraqi Criminal Tribunal } \\ \text { SPSC } & \text { Special Penals for Serious Crimes at Dili, East } \\ \text { TC } & \text { Timor } \\ \text { Tokyo Tribunal } & \text { Trial Chamber } \\ \text { UDHR } & \text { International Military Tribunal for the Far East } \\ \text { UN } & \text { Universal Declaration of Human Rights of 1948 } \\ \text { UN Charter } & \text { United Nations } \\ \text { UNTAC } & \text { Charter of the United Nations } \\ \text { the United Nations Transitional Authority in } \\ \text { WWII } & \text { Cambodia } \\ & \text { Second World War } \\ & \end{array}$




\section{Introduction}

\subsection{Background}

The doctrine of joint criminal enterprise liability (JCE) is a mode of individual liability in international criminal law. The notion of JCE is a form of liability that imputes criminal responsibility where two or more persons shared a common criminal plan as result of which crimes were committed. ${ }^{1}$ According to this doctrine, the members who formed the criminal plan are responsible not only for those crimes they agreed to, but for all other crimes that would be considered 'the natural and foreseeable consequence of the plan', irrespectively of whether those crimes were committed by person outside the criminal plan. ${ }^{2}$ The Appeals Chamber of the Tadić Case formed the JCE doctrine in its judgment in 1999 at the International Criminal Tribunal for the Former Yugoslavia (ICTY). ${ }^{3}$ Since then, the JCE has been consistently used and upheld in the ICTY and other international criminal tribunals.

The Extraordinary Chambers in the Courts of Cambodia (ECCC) is one of the United Nations (UN) hybrid courts, mentioned as one of international criminal tribunals, which was the result of the negotiations. ${ }^{4}$ It has been established by the Agreement between the UN and the Royal Government of Cambodia Concerning the Prosecution under Cambodia Law of Crimes Committed during the Period of Democratic Kampuchea, known as Khmer Rouge regime. The purpose of this Court is to bring the Khmer Rouge senior leaders and those most responsible to justice for the atrocities they committed under the regime. ${ }^{5}$ The Court has jurisdiction over senior leaders and those who were most responsible for the crimes and serious violations

\footnotetext{
${ }^{1}$ Prosecutor v. Ramush Haradinaj, Idriz Balaj \& Lahi Brahimaj, 3 April 2008, ICTY, Judgment, Case No. IT-04-84-T, para 135.

${ }^{2}$ Ibid.

3 See Prosecutor v. Duško Tadić, 15 July 1999, ICTY, Case No. IT-94-1-A, Appeal Judgment ['Tadić Appeal Judgment'].

4 The UN hybrid courts are also known as other terminologies such as mixed courts/tribunals; internationalized (criminal) courts/tribunals; mixed domestic-international tribunals; hybrid domestic-international courts; semi-internationalized criminal courts/tribunals; internationalized domestic courts/internationalized domestic tribunals; or mixed international/national institutions. The hybrid characteristic is the combination of the best of two worlds, the purely domestic and the purely international prosecution of international crimes. Besides the ECCC, there are some series of hybrid courts namely: the Serious Crimes Panels in the District Court of Dili in East Timor; the Regulation 64 Panels in the courts of Kosovo; the Special Court for Sierra Leone; the War Crimes Chamber in the Court of Bosnia and Herzegovina; the Iraqi Special Tribunal and the Ethiopian Special Prosecutor's Office; see generally S.M.H. Nouwen, “Hybrid Courts': The Hybrid Category of a New Type of International Crimes Courts', 2 Utrecht Law Review (2006) pp. 190 214.

${ }^{5}$ S.R. Ratner, Accountability for the Khmer Rouge: A (Lack of) Progress Report, in M.C. Bassiouni, Post-Conflict Justice (Transitional Publishers, New York, 2002) p. 614.
} 
of Cambodian penal law, international humanitarian law and custom, and international conventions recognized by Cambodia. ${ }^{6}$

The JCE first came to the ECCC by Ieng Sary, the second accused, in his Motion against the application of JCE at the ECCC on 28 July 2008. ${ }^{7}$ Due to the Motion, Ieng Sary argued on the inapplicability of JCE before the ECCC because it would violate the principle of nullum crimen sine lege, which prohibits a retroactive application of criminal law. ${ }^{8}$ Thus, Ieng Sary, in his Motion, requested the Office of Co-Investigating Judges (OCIJ) to declare that JCE is not a form of liability applicable before the ECCC. ${ }^{9}$

In the meanwhile, in the Case of Kiang Guek Eav alias Duch (Duch), the first accused, who chaired the detention, interrogation and execution camp called S-21 (also known as Toul Sleng) during the Khmer Rouge regime. The Co-Prosecutors found that the Co-Investigating Judges had erred their Closing Order to indict Duch for the commission of crimes through his participation in a JCE. ${ }^{10}$ Thus, the Co-Prosecutors, on 5 September 2008, appealed against the Closing Order by requesting the Pre-Trial Chamber (PTC) to amend the Indictment to include JCE liability although the crimes were committed during the Khmer Rouge regime. ${ }^{11}$

Following the appeal, the question regarding the application of JCE before the ECCC has become a controversial issue among international criminal law scholars and commentators. The key question on the prosecutorial aspects is that whether the ECCC can use JCE as a tool for taking into account the fact that the crimes were committed during the period 19751979. This problematic issue has been a significantly debated within the international community. ${ }^{12}$

\footnotetext{
${ }^{6}$ See the Law on the Establishment of Extraordinary Chambers in the Courts of Cambodia for the Prosecution of Crimes Committed during the Period of Democratic Kampuchea ['the ECCC Law'], Article 1 to Article 8.

${ }^{7}$ See generally Ieng Sary Case, Criminal Case File No. 002/19-09-2007-ECCC/OCIJ, ECCC, Ieng Sary's Motion against the Application at the ECCC of the Form of Liability known as Joint Criminal Enterprise ['JCE Motion’], 28 July 2008.

${ }^{8}$ Ibid., para. 29.

${ }^{9}$ See ibid.

${ }^{10}$ Case of Kaing Guek Eav alias Duch (hereinafter 'Duch Case'), Criminal Case File No. 001/18-07-2007-ECCC/OCIJ, ECCC, Closing Order Indicting Kaing Guek Eav alias Duch ['Closing Order'], 8 August 2008, paras. 153 - 161.

${ }^{11}$ Duch Case, Criminal Case File No. 001/18-07-2007-ECCC/OCIJ (PTC 02), ECCC, CoProsecutors' Appeal of the Closing Order Against Kaing Guek Eav “Duch” dated 8 August 2008 ['Appeal on Closing Order’]), 5 September 2008, paras. 11 - 12 and 73.

${ }^{12}$ See 'Civil party lawyers debate Joint Criminal Enterprise', The Phnom Phen Post, 23 November $2008<$ http://www.phnompenhpost.com/index.php/2008112322811/ThePost.blogs/civil-party-lawyers-debate-joint-criminal-enterprise.html>, accessed on 13 January 2010; J.L. Watkins and R.C. DeFalco, Nullum Crimen Sine Lege, the Jurisdiction of the Extraordinary Chambers in the Courts of Cambodia \& Joint Criminal Enterprise, p. 2, <www.dccam.org/Tribunal/Analysis/pdf/Nullum_Crimen_JCE_\&_The_ECCCWatkins_\&_DeFalco.pdf>, accessed on 3 February 2010; Moreover, three international criminal scholars were invited to submit written amici curiae briefs regarding such issue by the PTC; see Duch Case, Criminal Case File No 001-18-07-2007-ECCC-OCIJ (PTC 2),
} 
Ultimately, on 5 December 2008, the PTC in the Duch Case dismissed the appeal on the ground regarding the failure to include JCE as a mode of liability. However, the Co-Prosecutors continued their attempt to apply JCE against the accused before the ECCC by requesting the Trial Chamber (TC) for the application of JCE in the case against Duch on 8 June 2009. ${ }^{13}$

Almost one year after the dismissal by the PTC, on 8 December 2009, in the Ieng Sary Case, the Co-Investigating Judges issued a decision that all three categories can be applied against all accused. ${ }^{14}$ This study, therefore, examines the controversial application of JCE doctrine before the ECCC. Particularly, the study investigates the question of the legality and legitimacy of the application on JCE before the ECCC, where the application of the extended form of JCE (JCE III) would violate the principle of nullum crime sine lege.

Ordinarily, even the JCE as a prosecutorial tool in the Court, but the application of this doctrine in the case must respect the principle of nullum crimen sine lege. In this case, the fulfilment of the conditions for legality of the application; the existence of the law requirement and foreseeability and accessibility requirement, must be proven. Therefore, the conditions of the application of JCE before the ECCC must be satisfied in accordance with the principle of nullum crimen sine lege.

In most cases, the JCE is considered as one of the most effective and legitimate mode of liability in the prosecution, which can be employed to convict individual of core international crimes, where there is no direct evidence of the actual participation of the accused in the crime in question. Hence, the JCE applicability is still ambiguous on the legality question as stated above. One is whether the application of JCE is still legitimate. The other issue is whether the JCE is still considered as a legitimate tool in the prosecution. In answering these questions, the study will regard the relationship between legality, as condition of being legal and legitimacy, as condition of being within the law, of international criminal proceedings before the ECCC. ${ }^{15}$

ECCC, Invitation to Amicus Curiae, 23 September 2008 and 25 September 2008 ['Amicus Curiae Invitations'].

${ }^{13}$ See Duch Case, Criminal Case File No 001-18-07-2007-ECCC-TC, ECCC, CoProsecutors' Request for the Application of Joint Criminal Enterprise, 8 June 2009 ['Request for JCE'].

${ }^{14}$ See Ieng Sary Case, Criminal Case File 002/19-09-2007-ECCC/OCIJ, ECCC, Order on the Application at the ECCC of the Form of Liability Known as Joint Criminal Enterprise, 8 December 2009 ['Order on JCE'].

${ }^{15}$ See A. D'Amato, 'On the Legitimacy of International Institutions', in R. Wolfrum and V. Röben (eds.), Legitimacy in International Law (Springer, Berlin, 2008) pp. 83 - 92. 


\subsection{Purpose and Subject Matter}

The purpose of this thesis is to analyse the prosecutorial aspects of legality and legitimacy regarding the application of JCE as a tool in the prosecution of the former Khmer Rouge senior leaders for the crimes committed during the Khmer Rouge regime in the proceedings of the ECCC. This thesis seeks to examine the conceptual framework of JCE in the context of international criminal law i.e., the origins and the development of the doctrine; the categories and actus reus and mens rea elements; rationale of the doctrine as well as the legality and legitimacy of the use of JCE in the prosecution before international criminal tribunals.

The ad hoc tribunals jurisprudence shows that the application of JCE must respect the principle of nullum crimen sine lege, which is recognised as a fundamental principle of human rights law and international criminal law. Before embarking on the substantive analysis of the legality of the application of JCE, it is important to examine the concept of the principle of nullum crimen sine lege and the conditions for testing the application of JCE before the ECCC.

Since this thesis intends to analyse the legitimacy of the application of JCE before the ECCC, then the legitimacy of international criminal proceeding would be one of the jurisprudential concerns to be discussed in the study. In particular, the balancing tests on a case-by-case basis between the goals of human rights law and the goals of international criminal law. The purpose of the study is to determine whether JCE is a legitimate tool for prosecution before the ECCC.

\subsection{Methodology and Materials}

The fact is that the doctrinal concept of JCE emerged from the jurisprudence of the ICTY in the Tadic Case. Moreover, following the Tadić Case, the doctrine has been used and developed by the jurisprudence of international criminal tribunals. As such, the study mainly focuses on the reasoning through jurisprudence of the courts and tribunals regarding the use of JCE in the prosecution. The evaluation of the legality of the application of JCE in international criminal proceedings will involve examination of the jurisprudence of international criminal tribunals namely: the ICTY; the International Criminal Tribunal for Rwanda (ICTR); the International Criminal Court (ICC); the Special Court for Sierra Leone (SCSL); and the ECCC. The research methodology will be confined to literature review of the judgments and rulings of the ECCC including secondary sources such as textbooks and written of eminent publicists. ${ }^{16}$

\footnotetext{
${ }^{16}$ See for example Article 38 of the Statute of the International Court of Justice.
} 
The research will employ qualitative methodology in documentary analysis in the examination of the legality and legitimacy of the application of JCE. This will involve review of literature of relating to the application of JCE in the prosecutions of international criminal tribunals including judgments, decisions, opinions, orders and other related judicial documents.

\subsection{Delimitation}

Due to the limited scope of this study, the JCE mode of individual criminal liability for serious international crimes will be the main part for focusing on. To examine the conceptual framework of JCE, including the legality and legitimacy of the JCE applicability, the ambit of this study is limited to the jurisprudence of international criminal tribunals as mentioned above; ICTY, ICTR, ICC, SCSL and ECCC.

To analyse the legality and legitimacy of JCE liability before the ECCC, my scope of this study is limited to examining and analysis of the concept of JCE liability and the application of JCE before the ECCC. The main purpose of this study, therefore, is to investigate the conditions for applying the doctrine of JCE liability according to the principle of nullum crimen sine lege and analyse legitimacy of the application of JCE liability before the ECCC.

\subsection{Disposition}

Chapter contains the introduction, which gives a short procedural background of the application of JCE against the former Khmer Rouge senior leaders before the ECCC and the problematic issue about the application of JCE before the ECCC. Chapter 2, Framing the Doctrine of JCE in International Criminal Law, intends to examine the JCE. This will further give the conceptual framework of JCE liability in international criminal law. The chapter also examines JCE applicability before international criminal tribunals, in particular, the conditions for applying the doctrine and the testing of legality of JCE applicability and the legitimacy of the application of JCE in the prosecution.

Thereafter, Chapter 3, the Khmer Rouge Trials and the ECCC, gives a short background note on the Khmer Rouge regime and the emergence of internationalized hybrid court, the ECCC. The chapter reviews the jurisdiction: ratione temporis; ratione personae; and ratione materiae, of the ECCC and the modes of individual criminal responsibility under the ECCC Law will be examined.

Chapter 4, JCE Applicability and the ECCC, contains a discussion of the application of JCE before the ECCC. The chapter analyses the legality and legitimacy of the application of JCE as a prosecutorial tool before the 
ECCC. Moreover, the chapter analyses the legality of the application of JCE, in accordance with the principle of nullum crimen sine lege, as well as legitimacy of the application of JCE before the ECCC.

Finally, in Chapter 5 is the Conclusion, which outlines a number of conclusions, will be provided on the topic. 


\section{Framing the Doctrine of JCE in International Criminal Law}

The doctrine of JCE is a judicial innovation, which has grown to play a major role in the charges and convictions before international criminal tribunals. However, it is one of the most controversial modes of liability in international criminal law today. On one hand, the concept of JCE is widely accepted and routinely applied before international tribunals, for instance, ICTY, ICTR, SCSL the Supreme Iraqi Criminal Tribunal (SICT), the Special Penals for Serious Crimes of the District Court of Dili, East Timor (SPSC) and ECCC. The jurisprudence of those tribunals recognizes and reaffirms the lawfulness and effectiveness of the application of JCE in the prosecution against the accused, who committed serious international crimes, especially, the crimes of genocide, war crimes, and crimes against humanity, which includes torture.

On the other hand, the doctrine of JCE has also been highly attacked and criticised by international criminal law experts in many aspects, in particular, the expansiveness of the doctrine raises a prospect of 'guilty by association', and in some circle, JCE has been referred to as 'just convict everyone' ${ }^{17}$ In addition, this doctrine is going to challenges the legality and legitimacy of its application before the Special Penal for the Trial of Serious Crimes in East Timor, the Supreme Iraqi Criminal Court as well as the ECCC.

Therefore, the purpose of this chapter is to capture the conceptual framework of the doctrine of JCE in the context of international criminal law: the origins and development; categories; elements; and rationale of the application of JCE. As a mode of individual criminal responsibility, the application of this doctrine must respect the principle of legality (nullum crimen sine lege). Therefore, this chapter will examine the legality and legitimacy of the application of the doctrine of JCE as a prosecutorial tool in international criminal proceedings.

\subsection{An Overview of the doctrine of JCE}

Notably, the most of international criminal law violations are frequently perpetrated systematically and on a mass scale, requiring the coordinated action of numerous individuals. In other words, most of the acts, rendered as international crimes, which involve the actions or consent of more than one person. ${ }^{18}$ Thus, any person who becomes involved in any respect in a crime

${ }^{17}$ D. Robinson, 'The Identity Crisis of International Criminal Law', 21 Leiden Journal of International Law (2008) p. 939.

${ }^{18}$ C. de Than and E. Shorts, International Criminal Law and Human Rights (Sweet \& Maxwell, London, 2003) p. 7. 
committed by another may be held responsible for the action of the other, regardless of whether principal offender is arrested or punished or not.

Regarding this, the liability of each individual, who sharing in a common criminal purpose with others, contributes to the furtherance of that common criminal purpose with the direct intent to commit at least one crime falling within that purpose comes into question. Dealing with this question, if a person takes an active part in a crime with another, he or she may be charged as a co-perpetrator, similar to the concept of joint enterprise in common law criminal system. ${ }^{19}$ Then, that is the reason why the concept of JCE has been chosen as one of the mode of liability in international criminal tribunals.

Additionally, in the case of individuals in high-ranking positions such as political or military leadership, which contribute to criminal activity without physically committing of crimes have to be held responsible for such systematically international criminal law violations. Hence, JCE is an important and effective prosecutorial tool for capturing the criminal conduct of leaders' relation to large-scale crimes. ${ }^{20}$

As such, the doctrine of JCE is an important mode of individual criminal responsibility in the prosecution for international criminal tribunals to bring the suspected accused to justice.

\subsection{The Origins and Development}

There is a widely held view that the definition and scope of the concept of JCE was first mentioned in the ICTY as in the Tadic Appeal Judgment in 1999. ${ }^{21}$ Conversely, the origin of JCE is found in the events surrounding the end of the Second World War (WWII) and the first judicial pronouncement from the ICTY regarding the doctrine of JCE was in the Furundžija Trial Judgment in December $1998 .^{22}$ This section examines the origins and the development of the JCE liability from the jurisprudence of the international criminal tribunals by dividing into three periods namely: (i) post-WWII jurisprudence; (ii) The ICTY Jurisprudence: Furundžija case and Tadić case; and (iii) post-Tadić jurisprudence.

\footnotetext{
19 Ibid.

20 A. Cassese (ed.), The Oxford Companion to International Criminal Justice (Oxford University Press, New York, 2009) p. 392.

${ }^{21}$ G. Boas, J. L. Bischoff and N. L. Reid, International Criminal Law Practitioner Library Volume I: Forms of Responsibility in International Criminal Law (Cambridge University Press, New York, 2007) p. 10.

${ }^{22}$ Ibid.
} 


\subsubsection{Post-WWII Jurisprudence}

According to post-WWII trials before the International Military Tribunal at Nuremberg (Nuremberg Tribunal) and the International Military Tribunal for the Far East (Tokyo Tribunal), the Charters of those two Tribunals do not explicit provide any provision on the doctrine of JCE. The Charters, however, provide the provisions on the forms of criminal responsibility for the crimes against peace that:

“(a) CRIME AGAINST PEACE: namely, planning, preparation, initiation or waging a war of aggression, or a war in violation of international treaties, agreements or assurances, or participation in a common plan or conspiracy for the accomplishment of any of the forgoing,...,23

Due to such provision, any person who participated in a common plan or conspiracy to commit any foregoing crimes is responsible for all acts performed by any person in execution of such plan. These forms of liability, however, contained in the provisions of both Tribunals only applied to crimes against peace, and often called as conspiracy. ${ }^{24}$

However, the use of term of 'conspiracy' at the tribunals was only dealing with the situation where plans were put into effect. ${ }^{25}$ Importantly, this concept of conspiracy and common plan of the post-WWII tribunals separate from the offence of conspiracy in common law system. The offence of conspiracy is an agreement to commit an offence, ${ }^{26}$ which requires a showing that several individuals have agreed to commit a certain crime or set of crimes, while a conspiracy and common plan in the post-WWII trials, a joint criminal enterprise, requires that the parties to that agreement took action in furtherance of that agreement. ${ }^{27}$

Thus, the concept of JCE liability in ICTY is not a new concept, which the ICTY created, but this doctrine derived from the concept of conspiracy and common plan of post-WWII trials.

\footnotetext{
${ }^{23}$ Article 6 of the Charter of Nuremberg Tribunal and Article 5 (c) of the Charter of Tokyo Tribunal' Article 5 (c); emphasis added by author.

${ }^{24}$ R. Cryer et al., An Introduction to International Criminal Law and Procedure, (Cambridge University Press, Cambridge, 2008) p. 304; This form of liability requires an agreement between two or more parties to commit a crime, regardless of whether such crime is actually committed or not. Thus, leaders, organizers, instigators and compliances in the formulation or execution of a common plan or conspiracy to commit any of the forgoing crimes are responsible for all acts performed by any persons in execution of such plan, see C. Damgaard, Individual Criminal Responsibility for Core International Crimes, (Springer, Berlin, 2008) p. 185.

${ }^{25}$ Cryer et al., supra note 24, p. 305.

${ }^{26}$ Ibid., pp. $304-305$.

${ }^{27}$ Prosecutor v. Milan Milutinović, Nikola Šainović \& Dragoljub Ojdanić, 21 May 2003, ICTY, Decision on Dragolijub Ojdanić's Motion Challenging Jurisdiction - Joint Criminal Enterprise, Case No. IT-99-37-AR72, ['Ojdanić’s JCE Decision’], para. 36.
} 


\subsubsection{The ICTY Jurisprudence: Furundžija case and Tadić case}

Similarly, the Statute of the ICTY does not also contain any express provision on the form of JCE. Nevertheless, the ICTY has developed jurisprudence on the term JCE, especially in the Tadić Case in 1999.

As mentioned above, the concept of JCE derives from the concept of conspiracy and common plan at the post-WWII trials, however, the emergence of the term 'JCE' as well as the definition and its scope is created and introduced by the jurisprudence of the ICTY, especially in the Tadic Case. ${ }^{28}$ Surprisingly, the first judicial pronouncement from the ad hoc tribunals as to the definition and the scope of JCE was not the Tadic Appeal Judgment in 1999 as it is widely believed, but was the Furundžija Trial Judgment at the ICTY in $1998 .^{29}$

In the case of Anto Furundžija, a commander of the Bosnian Croat antiterrorist police unit known as the Jockers, the Trial Chamber held that the Chamber was 'empowered and obligated...to convict the accused under the appropriate head of criminal responsibility'. ${ }^{30}$ Accordingly, the Chamber examined several judgments for ascertaining the elements of aiding and abetting in customary international law by engaging in a detailed analysis of a number of post-WWII cases adjudicated pursuant to Control Council Law No. 10 (CCL No. 10) and the British Royal Warrant of $1945 .^{31}$ After the examination, the Chamber drew two categories of liability for criminal participation that appeared to have crystallised in international law, coperpetrators who participate in a JCE, on the one hand; and aiders and abettor, on the other hand. ${ }^{32}$

Some eight months after the Furundžija Case at the ICTY, Dusko Tadić was charged with responsibility via Article $7(1)$ of the Statute of the ICTY ${ }^{33}$ for the murder of five Bosnian Muslim men who were found dead in the village Jaskići following an attack on the village by an armed group, which included Tadić. $^{34}$

${ }^{28}$ Tadić Appeal Judgment, supra note 3, para. 191.

${ }^{29}$ See Prosecutor v. Furundžija, 20 December 1998, ICTY, Judgment, Case No. IT-96-21-

T ['Furundžija Trial Judgment'].

${ }^{30}$ Ibid., para. 189.

${ }^{31}$ Ibid., para. 191.

32 Ibid., para. 216; The Chamber held the distinction between aiding and abetting from the case of co-perpetration involving a group of persons pursuant a common design to commit crimes, Ibid., paras. 210, 212 - 213; Ultimately, the Chamber proceeded to find Furundžija guilty of torture as a 'co-perpetrator' and sentenced him to ten years' imprisonment for the torture conviction and eight years' imprisonment for the rape conviction, to be serve concurrently, ibid., paras. $256-257$

${ }^{33}$ Article 7 (1) of the Statute of the ICTY states that:

"A person who planned, instigated, ordered, committed or otherwise aided and abetted in the planning, preparation or execution of a crime referred to in articles 2 to 5 of the present Statute, shall be individually responsible for the crime."

${ }^{34}$ Prosecutor v Duško Tadić, 14 July 1997, ICTY, Judgment, Case No. IT-94-1-T, ICTY

['Tadić Trial Judgment'], para. 373; the Chamber concluded that it could not, 'on the 
In this case, the Appeals Chamber concerned that international crimes such as war crimes, crimes against humanity and genocide share a common feature: they tend to be expressions of collective criminality, in that they are perpetrated by groups of individuals, military details, paramilitary units or government officials acting in unison or in pursuance of a policy. ${ }^{35}$ According to this, the Chamber correctly acknowledged that:

"most of $[\ldots]$ these crimes [...] constitute manifestations of collective criminality: the crimes are often carried out by groups or individuals acting in pursuance of a common criminal plan.” 36

As a result, the Chamber then looked for a theory of international criminal participation that sufficiently takes into account the collective, widespread and systematic context of the commission of such crimes. The Chamber determined that it must be ascertained whether criminal responsibility of participating in a common purpose falls within the ambit of Article 7(1) of the Statute and held that while Article 7(1) covers first and foremost the physical perpetration of the crime by the offender himself, the commission of one of the crimes envisaged in Article 2, 3, 4 or 5 of the Statute might also occur through participation in the realization design and purpose. ${ }^{37}$

The Statute of the ICTY does not specify the physical and mental elements of such a form of responsibility, however, one must turn to customary international law to ascertain such elements ${ }^{38}$ The Chamber examined the judgments by IMTs and other post-WWII trials and categorised three distinct type of collective criminality. ${ }^{39}$ The first category (JCE I), the common enterprise cases, all co-defendants, acting pursuant to a common design, posses the same criminal intention to commit a crime, and one or more of them actually perpetrates the crime. The second category (JCE II), the concentration camp cases, the Chamber describes as really a variant of the first category, the common purpose was applied to instances where the offences charged were alleged to have been committed by members of military or administrative unit such as those running concentration camps and an organised criminal system exists in which detainees are systematically mistreated. Finally, the third category (JCE III), the foreseeable cases, the Chamber concerns cases involving a common design to pursue one course of conduct where one of the perpetrators commits an act which, while outside the common design, was nevertheless a natural and

evidence before it' be satisfied beyond reasonable doubt that the accused had any part in the killing the five men' at Jaskići. However, on the appeal, the prosecution argues that Tadic should have been convicted of the killing pursuant to the 'common purpose' doctrine as the only reasonable inference that could be drawn from the evidence was that the killings were a natural and probable consequence of the attack on Jaskici and occurred pursuant to a broader policy to rid the region of non-Serbs, see Tadić Appeal Judgment, supra note 3, para. 175.

${ }^{35}$ Tadić Appeal Judgment, supra note 3, para. 191.

${ }^{36}$ Ibid, para. 185.

${ }^{37}$ Ibid, paras. 187 - 188.

${ }^{38}$ Ibid, para. 194.

${ }^{39}$ Ibid, para. 195. 
foreseeable consequence of the effecting of that common purpose. ${ }^{40}$ The precise characteristics and elements of all the three categories of JCE will be discussed in section 2.3 and 2.4 of this chapter.

Subsequently, at the end of the appeal, the Appeals Chamber overturned his acquittal, set out the understanding of liability by virtue of participation in a JCE in the ambit of commission in Article 7(1) of the Statute of the ICTY and held Tadić responsible for the murder of the five men at Jaskići pursuant to JCE III. The Chamber found that it was foreseeable that nonSerbs might be killed in the execution of the common plan and that Tadic had been aware that the actions of his associates were likely to lead to such killing. ${ }^{41}$ The Appeals Chamber convicted Tadić of wilful killing as a grave breach, murder as a violation of the laws and customs of war, and murder as a crime against humanity. ${ }^{42}$

\subsubsection{Post-Tadić Jurisprudence}

Since Tadić, the ICTY Appeals Chambers has consistently held that 'committing' implicitly encompass participation in JCE, even though that term does not expressly appear anywhere in the Statute. ${ }^{43}$ Moreover, the doctrine of JCE has been often reaffirmed, upheld and criticised by the jurisprudence of other international criminal tribunals, i.e., ICTR, SCSL and ICC. As a result, the concept of JCE has been developed by those judicial pronouncements. This sub-section will examine the development of the JCE aftermath the remarkable case of Tadić.

\subsubsection{ICTY}

By nature of core international crimes, most of them are committed by a plurality of perpetrators. Unsurprisingly, since the Tadić Appeal Judgment, the JCE has been used extensively in the indictments at the ICTY as a tool for bringing to justice perpetrators of serious international crimes in the Former Yugoslavia. The Case of Milošević, the most well known case, the prosecution also relied on this mode of liability. ${ }^{44}$

\footnotetext{
${ }^{40}$ Ibid, paras. 196, 202, 204.

${ }^{41}$ Ibid, para. 232.

${ }^{42}$ Ibid, paras. 235 - 237.

43 G. Boas, 'The Difficulty with Individual Criminal Responsibility in International Criminal Law' in C. Stahn and L. van den Herik (eds.), Future Perspectives on International Criminal Justice (T·M·C Asser Press, The Hague, The Netherlands, 2010) p. 510.

${ }^{44}$ See Prosecutor v. Slobodan Milošević, Milan Milutinović, Nikola Šainović, Dragoljub Ojdanić and Vlajko Stojijkovic, 16 October 2001, ICTY, Second Amended Indictment, Case No. IT-99-37-PT; Prosecutor v. Slobodan Milošević, 22 November 2001, ICTY, Amended Indictment, Case No. IT-02-54-T; and Prosecutor v. Slobodan Milošević, 23 October 2002, ICTY, Second Amended Indictment, Case No. IT-01-50-I.
} 
In addition, as an applicable prosecutorial tool, JCE has been developed by the ICTY jurisprudence in many occasions after the Tadić Case. ${ }^{45}$ The permissibility of imposing liability pursuant to this doctrine under the Statute of the ICTY has been reaffirmed. Furthermore, physical and mental elements set forth in Tadic Case have been substantially refined and expanded. $^{46}$ In addition, the customary status of JCE in international customary law and the judicial pronouncement that JCE falls within the ambit of 'commission' under Article 7(1) of the Statute of the ICTY were reasserted. ${ }^{47}$

\subsubsection{The Jurisprudence of the ICTR as regards JCE}

Although JCE has been recognised by the ICTY jurisprudence since the Tadić Case in 1999, indeed, it has become the 'magic bullet' of prosecutors at the international criminal tribunals, as William Schabas describes, but the prosecutor of ICTR has been slow to incorporate clear charge of JCE participation into the indictments. ${ }^{48}$ At the ICTR, the role of JCE has not been as significant as it has been in the ICTY. There are few Chambers have even pronounced on the application of JCE, however, there are some developments of JCE, which established by the ICTR jurisprudence.

In the Rwamakuba Case, the Chamber recognised JCE for genocide existed in customary international law prior to $1992 .{ }^{49}$ Therefore, the ICTR had jurisdiction over a charge of genocide perpetrated through JCE. The Karemera Case, the Chamber discussed on the use of JCE both to international and internal armed conflicts and whether, if it does, this amount to a breach of the nullum crimen sine lege principle. $^{50}$ The Ntakirutimana and Ntakirutimana Case, the Chamber examined the elements of JCE in terms, which are identical to those set forth in the Vasilijevic Appeal Judgment of the ICTY and concluded that the

\footnotetext{
45 The existence of the common-purpose doctrine referred by the term 'JCE', regarding this the Appeals Chamber held that those two phases had been use interchangeable in the practice and jurisprudence of the ICTY, and the JCE is preferred, see Ojdanić's JCE Decision, supra note 27, para. 36; Prosecutor v. Radoslav Brđanin, 26 June 2001, ICTY, Pre-Trial Decision, Case No. IT-99-36-PT, para. 24.

${ }^{46}$ Prosecutor v. Stakić, 22 March 2006, ICTY, Judgment, Case No. IT-97-24-A, paras. 6465; Prosecutor v. Blaškić, 29 July 2004, ICTY, Judgment, Case No. IT-95-14-A, para. 33; Prosecutor v. Dalalic, Mucic, Delic and Landzo, 20 February 2001, ICTY, Judgment, Case No. IT-96-21-A, paras. 345, 366.

47 Prosecutor v. Milan Milutinović, Nikola Šainović \& Dragoljub Ojdanić, 5 September 2002, ICTY, Third Amended Indictment, Case No. IT-99-37-1, para. 16.

${ }^{48}$ W.A. Schabas, 'Mens Rea and the International Criminal Tribunal for the Former Yugoslavia’, 37 New England Law Review (2003) p. 1032.

49 Prosecutor v. Rwamakuma, 22 October 2004, ICTR, Decision on Interlocutory Appeal Regarding Application of Joint Criminal Enterprise to the Crime of Genocide, Case No. ICTR-98-44-AR72.4, para. 31.

${ }^{50}$ Prosecutor v. Edourad Karemera, Mathieu Ngirumpatse, Joseph Nzirorera and Andre Rwamakuba, 11 May 2004, ICTR, Decision on the Preliminary Motions by the Defence of Joseph Nzirorera, Edourad Karemera, Andre Rwamakuba and Mathieu Ngirumpatse Challenging Jurisdiction in Relation to Joint Criminal Enterprise, Case No. ICTR-98-44-T ['Karemara JCE Decision'], paras. 1 - 30.
} 
jurisprudence of the ICTY should be applied to the interpretation of Article $6(1)$ of the ICTR Statute. ${ }^{51}$

\subsubsection{The Philosophy of the ICC on the doctrine of JCE}

The Rome Statute of the ICC is the first international instrument that explicitly regulates JCE doctrine. It does not resemble those of the Statutes of the ICTY and ICTR in that Article 25(3) (d) of the Rome Statute expressly deals with the doctrine of JCE. ${ }^{52}$ If the ICC has not had the judicial pronouncements as much as ad hoc tribunals, however, there are some JCE developments at the ICC, at least, in the first case against Lubanga Dylio.

In the Lubanga Case, Pre-Trial Chamber took the view that Article 25(3) (d) refers to a concept of co-perpetration based on the notion of 'joint control' over the crime. ${ }^{53}$ Then, the major difference between the ICC Chamber's concept of joint control and JCE is that joint control requires the accused to make an essential contribution such that the commission of the crime would be frustrated if the contribution were withdrawn. ${ }^{54}$

\subsubsection{The reasoning of the SCSL vis-à-vis JCE}

As a hybrid court, the SCSL operates on a 'shoe-string budget' and is mandated 'to prosecute persons who bear the greatest responsibility for serious violations of international humanitarian law and Sierra Leonean law

${ }^{51}$ Prosecutor v. Ntakirutimana and Ntakirutimana, 13 December 2004, ICTR, Judgment, Case Nos. ICTR-96-10-A and ICTR-96-17-A ['Ntakirutimana Appeal Judgment'], para. 468.

${ }^{52}$ Article 25(3) (d) of the Rome Statute of the ICC states that:

" 3 . In accordance with this Statute, a person shall be criminally responsible and liable for punishment for a crime within the jurisdiction of the Court if that person...

(d) In any other way contributes to the commission or attempted commission of such a crime by a group of persons acting with a common purpose. Such contribution shall be intentional and shall either:

i) Be made with the aim of furthering the criminal activity or criminal purpose of the group, where such activity or purpose involves the commission of a crime within the jurisdiction of the Court; or

ii) Be made in the knowledge of the intention of the group to commit the crime;..."

see generally A. Eser, 'Individual Criminal Responsibility', in A. Cassese, P. Gaeta and J.R.W.D. Jones (eds.), The Rome Statute of the International Criminal Court: A Commentary Volume I (Oxford University Press, New York 2002) pp. 802 - 803; O. Triffterer, Commentary on the Rome Statute of the International Criminal Court: Observers' Notes, Article by Article, $2^{\text {nd }}$ edn. (Hart, Oxford 2008) pp. 760 - 763; W.A. Schabas, The International Criminal Court: A Commentary on the Rome Statute (Oxford University Press, New York 2010) pp. 430 - 437.

53 Prosecutor v. Lubanga Dylio, 29 January 2007, ICC, Decision on the Confirmation of Charges, Case No. ICC-01/04-01/06-803, paras. 317 - 367.

${ }^{54}$ Cassese (ed.), supra note 20, p. 393. 
committed in the territory of Sierra Leone since 30 November 1996. ${ }^{55}$ Even though the SCSL is not obliged to apply the jurisprudence of the ICTY and ICTR, but the SCSL does so for its 'persuasive authority' given that the SCSL and the ad hoc international criminal tribunals are part of the same system of international criminal justice. ${ }^{56}$ Article 6 (1) of the SCSL Statute contains the provision, which is clearly modeled on the Article 7(1) of the Statute of the ICTY and Article 6(1) of the Statute of the ICTR. Even though it does not expressly provide for the doctrine of JCE, but the court has determined that the term 'commit' is sufficiently protean in nature to conclude participation in a JCE to commit the crime. ${ }^{57}$

The doctrine of JCE is playing an important role before the SCSL. Each of current outstanding indictments before the SCSL charges the accused with JCE. ${ }^{58}$ Recently, in the Sesay et al. Case, the Appeals Chamber held the important jurisprudence on the JCE. ${ }^{59}$ According to the case, the JCE does not require that an accused should share the intent of the other participants in that JCE to commit the crimes that are said to be within its common purpose or goal. ${ }^{60}$ Thus, with or without that intent, a defendant charged pursuant to that theory of liability may be held criminally responsible for all the natural and foreseeable consequences of that enterprise, however remote they might have been from the defendant's own intentions. ${ }^{61}$

\subsubsection{The doctrine of JCE in the ECCC}

The ECCC was established for prosecuting the former Khmer Rouge senior leader for crimes committed during the Democratic Kampuchea regime (during 1975-1979). The ECCC Law does not specifically provide for the doctrine of JCE, but employs terms similar to Article 7(1) of the ICTY Statute in Article 29 of the ECCC Law that:

“Any Suspect who planned, instigated, ordered, aided and abetted, or committed the crimes referred to in article 3 new, 4, 5, 6, 7 and 8 of this law shall be individually responsible for the crime..."

55 J. Easterday, 'Obscuring Joint Criminal Enterprise Liability: The Conviction of Augustine Gbao by the Special Court of Sierra Leone’, 3 Berkley Journal of International Law Publicist (2009) p. 39.

${ }^{56}$ Damgaard, supra note 21, pp. 51 - 55; see Prosecutor v. Alex Tamba Brima, Brima Bazzy Kamara and Santigie Borbor Kanu, 20 June 2007, SCSL, Judgment, Case No. SCSL-04-16-T.

${ }^{57}$ Prosecutor v. Moinina Fofana and Allieu Kondewa, 2 August 2007, SCSL, Judgment, Case No. SCSL-04-14-T, para. 208.

${ }^{58}$ See Prosecutor v. Charles Ghankay Tayler, 16 March 2006, SCSL, Amend Indictment, Case No. SCSL-03-01-I-001; Prosecutor v. Johnny Paul Koroma, 3 March 2003, SCSL, Indictment, Case No. SCSL-2003-03-I; Prosecutor v. Foday Saybana Sankoh, 3 March 2003, SCSL, Indictment, Case No. SCSL-2003-02-I-001 and Prosecutor v. Sam Bockarie, 3 March 2003, SCSL, Indictment, Case No. SCSL-2003-04-I.

${ }^{59}$ See Prosecutor v. Issa Hassan Sesay, Morris Kallon and Augustine Gbao, 26 October 2009, SCSL, Appeal Judgment, Case No. SCSL-04-15-A ['Sesay et al. Appeal Judgment'].

60 G. Mettraux, “Joint Criminal Enterprise” has Grown Another Tentacle!, <http://www.internationallawbureau.com/blog/?p=944> accessed 20 April 2010.

${ }^{61}$ Ibid; Sesay et al. Appeal Judgment, supra note 56, para. 492, and Justice Shireen Avis Fisher Dissent, paras. $17-22$. 
Additionally, until present, the issue of the application of JCE against the accused at the ECCC still has been a controversial issue among international criminal experts. The questions on the legality and legitimacy of the application of JCE before the ECCC are still ambiguous.

The main purpose of this thesis is to analyse the problematic issue of the legality and legitimacy of the application of JCE before the ECCC, which is discussed in Chapter 4 of this study.

\subsubsection{The Application of JCE in other Hybrid Courts}

Besides, the SCSL and the ECCC, the doctrine of JCE also play role as a prosecutorial tool in the Statutes of other hybrid courts. For instance, Article 15(2) (d) of the Law of the SICT explicitly recognised the doctrine of JCE as a separate mode of liability, in terms similar to Article 25(3) (d) of the Rome Statute of the ICC. ${ }^{62}$ The prosecution of Saddam Hussein and six of seven of his co-accused were convicted of almost all the crimes with which they were charged, through principle forms of responsibility, including common-purpose liability. ${ }^{63}$

Similarly, Section 14 of the Regulation No. 2000/15 on the Establishment of Penals with Exclusive Jurisdiction over Serious Criminal Offence of the SPSC, promulgated by the UN Transitional Administration in East Timor (UNTAET) mirrors Article 25 of the Rome Statute of the ICC. Additionally, the prosecution's submission of the SPSC elaborated upon the notion of participation in common purpose with particular based on the jurisprudence of the ad hoc tribunals. ${ }^{64}$

\subsection{Categories of JCE}

According to the ICTY jurisprudence in the Tadic Case, the Appeals Chamber distinguished, relying on post-WWII case law, collective criminality into three categories: basic, systemic and extended forms. ${ }^{65}$ The Appeals Chamber concluded that international responsibility embraces actions perpetrated by collectively by persons in furtherance of a common criminal design. ${ }^{66}$ After review the post-WWII cases, the Appeal Chamber identified the following three categories of JCE. This section will consider the characteristics of each category of such doctrine.

\footnotetext{
${ }^{62}$ See the Law of the Supreme Iraqi Criminal Tribunal, No. 10 of 1005, Official Cazette of the Republic of Iraq, No. 4006, 47 ${ }^{\text {th }}$ year, 18 October 2005. An English translation of the law is available at <www.ictj.org/static/MENA/Iraq/iraq.statute.engtrans.pdf $>$, accessed 14 March 2010.

${ }^{63}$ Boas, Bischoff and Reid, supra note 21, pp.139 -140.

${ }^{64}$ Ibid., pp. 133 - 135; e.g. Prosecutor v. José Cardoso Fereira, 5 April 2003, SPSC, Judgment, Case No.. 04/2001, para. 367, the penal concluded that '[t]he Accused...is responsible for committing the crime of imprisonment or serve deprivation of liberty in violation of fundamental rules of international law under Section 14.3(a) of UNTAET Regulation 2000/15 pursuant to a joint criminal enterprise in effect' these crimes.

65 Tadić Appeal Judgment, supra n. 3, para. 111.

${ }^{66}$ Ibid., para 193.
} 


\subsubsection{JCE I: The Basic Form}

JCE I is the liability for a common criminal purpose; the basic form where the participants act on the basis of a 'common design' or 'common enterprise' and with a common 'intention'. Cases where all co-perpetrators, acting pursuant to a common design posses the same criminal intention such as the formulation of a plan among the co-perpetrators to kill, where, in effecting this common design, and even if each co-perpetrator carries out a different role within it, they nevertheless all purpose the intend to kill. The accused must 'voluntary participate' in one aspect of the common design, for instance, by inflicting non-fatal violence upon the victim, or providing material assistance to, or facilitating the activities of his co-perpetrators. ${ }^{67}$

Some of the important cases referred by the Chamber as an example of JCE I was the Trial of Otto Sandrock and three others (known as "Almeno Trial”), which three Germans had killed a British prisoner of war (POW), were found guilty by the British Military Court under the doctrine of 'common enterprise'. In addition, the Hoelzer et al. Case before a Canadian Military court, where the Judge spoke of a 'common enterprise' with regard to the murder of a Canadian POW by the three Germans. ${ }^{68}$

\subsubsection{JCE II: The Systemic Form}

JCE II is the liability for participation in an institutionalised common criminal plan. The systemic form, that is, the so called concentration camp cases where crimes were alleged to have been committed by members of military of administrative units acting pursuant to a 'concerted plan', such as those running concentration or detention camps on the basis of a "common plan." 69

The two well-known examples of JCE II are the Trial of Martin Gottfried Weiss and thirty-nine others (known as "the Dachua Concentration Camp Case"), decided by a United States Military Court and the Trial of Jose Kramer and forty-four other (know as "Belsen Case”), decided by a British Military Court. ${ }^{70}$ In both cases, the accused held positions of authority within the concentration camps where they worked and were charged with having acted in pursuance of a common design to mistreat or kill detainees. The guilt of the accused via JCE II, however, has to fulfill three requirements: (i) the existence of an organised system of ill-treatment of the detainees and the committing of the crime alleged; (ii) the accused's awareness of this system; and (iii) the active participation of the accused in the enforcement of such system, or in any case, in the realisation of the 'common criminal design'. ${ }^{71}$

\footnotetext{
${ }^{67}$ Ibid., para 196.

${ }^{68}$ Ibid., para 197.

${ }^{69}$ Ibid., para 202.

${ }^{70}$ Ibid.

${ }^{71}$ Ibid.
} 


\subsubsection{JCE III: The Extended Form}

JCE III is an incidental criminal liability based on foresight and voluntary assumption of risk. The extended form where one of the co-perpetrators actually engages in acts going beyond the common plan, but his or her acts constitute a "natural and foreseeable consequence" of the realization of the plan, and the accused willingly tool the risk that that natural and foreseeable consequence would occur. ${ }^{72}$

The two important examples of JCE III are the Case of Essen Lynching Heyer and six others (known as the "Essen Lynching Case or Essen West Case") which the accused were convicted had to have been "concerned in the killing' of the prisoners ${ }^{73}$ and the Kurt Goebell et al.Case (called the "Borkum Island Case") before a United States military court that all the accused found guilty were held responsibility for pursuing a criminal common design, the intent being to assault the POWs.

\subsection{Elements of JCE}

The Appeals Chamber in the Tadić Case not only unified and identified the three separate categories of JCE, but also classified the subjective and objective elements of each category in its Judgment. Moreover, all of these elements have repeatedly reasserted by the jurisprudence of both ad hoc tribunals, ICTY and ICTR. This section will review the actus reus element and the mens rea element of each category of JCE due to the jurisprudence of the international criminal tribunals.

\subsubsection{Subjective Elements (actus reus)}

The Aftermath of Tadić, both ICTY and ICTR have followed the Tadić jurisprudence lead in articulating three broad physical elements (actus reus) common to all categories of JCE liability, that is:

a) a plurality of persons;

b) the existence of a common plan, design or purpose which amount to or involves the commission of a crime provided for in the Statute and;

c) participation of the accused in the common design involving the perpetration of one of the crimes provided for in the Statute. ${ }^{74}$

Each of these elements has slightly difference in appearance, which is address in the following part.

\footnotetext{
${ }^{72}$ Ibid., para. 204; see also Damgaard, supra note 24, p. 142.

73 Tadić Appeal Judgment, supra note 3, para. 209.

${ }^{74}$ Ibid., para 227.
} 
According to the Tadic Appeal Judgment, the first actus reus element for all categories of JCE is the consistence of a plurality of persons. Moreover, the element makes up the JCE need not be organised in a military, political or administrative structure. ${ }^{75}$ The post-Tadic jurisprudence of ad hoc tribunals, reaffirmed this first element that the JCE to arise an accused must act with a number of other persons. In the Ntakirutimana and Ntakirutimana Appeal Judgment, the Chamber referred that plurality requirement must consist of many people ${ }^{76}$; however, several trial judgments have made it clear that two persons are sufficient to form a JCE. ${ }^{77}$

\section{Common plan, design or purpose}

Regarding this, the Tadić Appeal Judgment set out this element that the prosecution must prove the existence of a common plan, design or purpose which amount to or involves the commission of a crime provided for in the Statute. ${ }^{78}$ Subsequent judgments have restated this requirement by using one or more of these three seemingly interchangeable terms. ${ }^{79}$

Moreover, the Tadić Appeal Judgment held that there is no necessity for this plan, design or purpose to have been previously arranged or formulated. The common plan or purpose may materialise extemporaneously and be inferred from the fact that a plurality of persons acts in unison to put effect a JCE. ${ }^{80}$ This passage of Judgment has been restated in post-Tadić Judgment that the existence of an agreement or understanding for the common plan, design or purpose need not be express, but may be inferred from all the circumstances. $^{81}$

\section{(iii) The accused participated in the JCE}

The third actus reus element of JCE, as set forth in the Tadic Appeal Judgment and repeated many time in post-Tadic Case judgments, is the participation of the accused in the common design involving the perpetration of one of the crimes provided for in the Statute. This participation need not involve commission of a specific crime under one of those provision (for example, murder, extermination, torture, rape, etc.), but may take the form of assistance in, or contribution to, the execution of the common plan or purpose. ${ }^{82}$

\footnotetext{
${ }^{75}$ Ibid.

${ }^{76}$ Ntakirutimana Appeal Judgment, supra note 51, para. 466.

${ }^{78}$ Tadić Appeal Judgment, supra note 3, para. 227.

${ }^{79}$ Boas, Bischoff and Reid, supra note 21, p. 37.

${ }^{80}$ Tadić Appeal Judgment, supra note 3, para. 227.

${ }^{81}$ Boas, Bischoff and Reid, supra note 21, p. 37.

${ }^{82}$ Tadić Appeal Judgment, supra note 3, para. 227.
}

${ }^{77}$ The Prosecutor v. Miroslav Kvočka, Dragoljub Prcać, Milojica Kos, Mlaño Radić \& Zoran Žigić, 2 November 2001, ICTY, Judgment, Case No. IT-98-30/1-T å‘Kvocka et al. Trial Judgment'], para. 307; Prosecutor v. Radoslav Brđanin, 1 September 2004, ICTY, Judgment, Case No. IT-98-33-T ['Brđanin Trial Judgment'], para. 262. 


\subsubsection{Objective Elements (mens rea)}

While the actus reus element of all three categories are exactly the same, the mens rea elements of each category of JCE is distinguished separately. JCE I requires the shared intent of the co-perpetrators, JCE II requires the perpetrator's personal knowledge of the system of ill-treatment and JCE III required the perpetrator's intention to participate in the criminal purpose, to further this purpose and to contribute to the commission of the crimes by the group. $^{83}$

\section{(i) Mens rea element of JCE I}

The Tadic Appeal Judgment held that the mens rea element of the JCE I that the accused must have the intent to perpetrate a certain crime. ${ }^{84}$ However, the jurisprudence of $a h$ hoc tribunals indentifies physical or objective elements of JCE I into two elements, that is, voluntary participation and shared intent. Regarding the first element, the jurisprudence requires the voluntarily participation in one aspect of the common plan; the accused voluntarily participated in the enterprise and intended the criminal result. ${ }^{85}$

(ii) Mens rea element of JCE II

According to the Tadic Case, the mens rea elements of the second category, which relates to 'system of ill-treatment' such as concentration or detention camp, the accused must have personal knowledge of the system of illtreatment as well as the intent to further this common concerted such system. $^{86}$

(iii) Mens rea element of JCE III

Considering the Tadić Case, the mens rea element of JCE III covers crimes that fall outside the common plan. The accused must intend to participate in and further the criminal activity or the criminal purpose of a group and to contribute to the JCE. Liability for the crime other than the one agreed upon in the common plan arise only if, under circumstances of the case (i) it was foreseeable that such a crime might be perpetrated by one or other members of the group and (ii) the accused willingly took that risk. ${ }^{87}$

${ }^{83}$ Ibid., paras 196, 202, 220 and 228.

${ }^{84}$ Ibid., para. 228.

${ }^{85}$ Boas, Bischoff and Reid, supra note 21, p. 51.

${ }^{86}$ Tadić Appeal Judgment, supra note 3, para. 228.

${ }^{87}$ Ibid. 


\subsection{Distingushing JCE Liability and Aiding and Abetting Liability}

Notable, as abovementioned in sections 2.3 and 2.4 regarding the categories and elements of the JCE show that the JCE is not a crime but a form of individual criminal responsibility, which is a separate mode of liability in its own right. JCE has its own specific actus reus and mens rea elements for each category.

However, there is much more confusion surrounding the JCE concept and other modes of liability because of its prima facie similarity to other modes of liability, in particular, the aiding and abetting, as such term is understood in international criminal law. ${ }^{88}$ Interestingly, the origins of the JCE concept are to be found in the concept of aiding and abetting. Thus, this section aims to distinguish JCE from aiding and abetting mode of individual criminal liability under international criminal law.

Aiding and abetting is a form of complicity in criminal activity that involves assisting or encouraging the principal perpetrator of a criminal offence. The existence of liability for this mode is uncontroversial; it is recognised, for example in Article 7(1) of the ICTY Statute, Article 6(1) of the ICTR Statute and Article 6(1) of the SCSL Statute, all of which criminalise 'a person...who aided and abetted in the planning, preparation or execution' of an international crime.

In addition, in the Statute of the ICC covers aiding and abetting in Article 25(3)(c), which includes liability for persons who “...[f]or the purpose of facilitating the commission of such a crime, aids, abets or otherwise assists in its attempted commission, including providing the means for its commission;...". ${ }^{89}$ This means that an aider and abettor is only liable for complicity in crimes that are consummated in either a completed crime or, at the very least, an attempt. ${ }^{90}$

The law of aiding and abetting in the ad hoc tribunals is largely explained in the Furundžija Case and the Tadić Case. ${ }^{91}$ The jurisprudence set out the requirements of such liability in international criminal law are the actus reus consists of practical assistance, encouragement, or moral support which has a substantial effect on the perpetration of the crimes and the mens rea required in the knowledge that these acts assist the commission of the offence. Then, this notion of aiding and abetting is distinguished from the notion of common design, where the actus reus consists of participation in a JCE and the mens rea required is intent to participate.

\footnotetext{
${ }^{88}$ Damgaard, supra note 24, p. 182.

89 Emphasis added by author.

${ }^{90}$ Cassese (ed.), supra note 21, p. 239.

91 Furundžija Trial Judgment, supra note 29, para. 249; Tadić Appeal Judgment, supra note 3, para. 229.
} 
Even between aiding and abetting mode and JCE, they look as similar concepts, but they are distinguished from each other and have some differences between them. The similarity and differences are discussed in the Tadić Case and the Kvočka Case at the ICTY. The main difference is that an aider or abettor does not need to know of any common plan, but his or her assistance must be substantial. An aider or abettor is only responsible for crime known, whereas foresight by the defendant suffices for liability for crimes committed pursuant to a JCE. The accused knows that his assistance is supporting the crimes of a group of persons involved in a JCE and shares that intent, and then he may be found criminally responsible for the crimes committed in furtherance of that common purpose as a co-perpetrator. ${ }^{92}$

Moreover, in some circumstances the aiding and abetting mode and JCE are overlap, or in some cases could arguably be that JCE fit within the aiding and abetting mode of liability as articulated in the ICTY and ICTR Statutes and interpreted by the ICTY and ICTR. ${ }^{93}$ Nevertheless, there are clear differences between those two modes of liability.

\subsection{Rationale of JCE doctrine}

The reason for the application of JCE is that any person who becomes involved in any respect in a crime committed by another may be held responsible for the action of the other, regardless of whether principal offender is prosecuted or not. Thus, if a person takes an active part in a crime with another, he may also be charged as a co-perpetrator, on a basis similar to that of joint enterprise. ${ }^{94}$

According to the ad hoc tribunals jurisprudence, the rationale of the JCE liability in the prosecution has been identified by the ICTY in the following terms:

“[T]o hold criminally liable as a perpetrator only the person who materially performs the criminal act would disregard the role as co-perpetrators of all those who in some way made it possible for the perpetrator physically to carry out that criminal act. At the same time, depending upon the circumstances, to hold the latter liable only as aiders and abettors might understate the degree of their criminal responsibility. ${ }^{95}$

Regarding this, one can appreciate the desire to punish as many of the perpetrators of core international crimes as possible. In addition, the doctrine deems the accused to have committed the crime, and indeed deems all members to be equally guilty of the crimes regardless of the part played

\footnotetext{
92 Ibid.; see also Prosecutor v. Miroslav Kvočka, Dragoljub Prcać, Milojica Kos, Mlão Radić \& Zoran Žigić, 28 February 2005, ICTY, Appeal Judgment, Case No. IT-98-30/1-A ['Kvočka et al. Appeal Judgment'], para 90.

${ }^{93}$ K. Ambos, 'Joint Criminal Enterprise and Command Responsibility', 5 Journal of International Crimnal Justice (2007) p. 171.

${ }_{94}$ Than and Shorts supra note 18, p. 7.

${ }^{95}$ Karemara JCE Decision, supra note 50, para. 36.
} 
by each in its commission. ${ }^{96}$ Importantly, the contribution need not entail physical participation in any element of a crime. ${ }^{97}$

JCE has been recognized as a valuable tool in securing the convictions; the doctrine has been being applied for prosecuting the accused before the international criminal tribunals since the Tadić Case until present. In the same time, the doctrine continued to develop through generous judicial interpretation. Due to this, commentators have begun to question the doctrine's conformity with fundamental principles. Some commentators argued that the expansiveness of the doctrine raises a prospect of guilt by association. In particular, the application of JCE III has been referred to as 'just convict everyone'. 98

Furthermore, JCE enables the evidentiary difficulties of proving that the accused participated in a crime to be circumvented and for the accused to be convicted of participation in a core international crime. ${ }^{99}$ The process by which JCE was judicially introduced is problematic in terms of the principle of legality. It contradicts the fundamental principle in several ways; in particular, the violation of the principle of nullum crimen sine lege has been brought in the proceedings. ${ }^{100}$

According to the jurisprudence of international criminal tribunals, it does not present JCE as a necessary exemption to fundamental principle, but rather as fully consistent with them. Then, the application of JCE must respect the fundamental principles of international criminal law such as the right to fair trial, the presumption of innocent and the punishment of personal guilt of the individual. ${ }^{101}$

As a result, the application of JCE has been criticised by commentators because it contradicts the rationale for the traditional strict evidentiary requirements, which must be satisfied for a conviction, is to ensure that an innocent man is not convicted, which is the goal of human rights law. Importantly, the consequences of conviction for a core international crime

${ }_{97}^{9}$ Ojdanić's JCE Decision, supra note 27, para. 20; Robinson, supra note 17, p. 939.

97 Kvočka et al. Appeal Judgment, supra note 92, para. 99; Prosecutor v. Radoslav Brđanin, 3 April 2007, ICTY, Appeal Judgment, Case No. IT-98-36-A ['Brđanin Appeal Judgment'], para. 427.

${ }^{98}$ See M.E. Bardar, “ “Just Convict Everyone!” - Joint Perpetration: From Tadić to Stakić and Back Again’, 6 International Criminal Law Review (2006) pp. 293 - 302.

99 Damgaard, supra note 24, p. 235.

${ }^{100}$ See generally Ojdanić's JCE Decision, supra note 27; JCE liability is in problematic in term of culpability and fair labeling, for instance, a negligible contribution can result in massive criminal liability, then the accused need not to perform any part of the actus reus element of any crime, there are no legal limits on its scope and according to the doctrine, all members to be equally guilty of the crimes regardless of the part played by each in its commission, then the low-level individual making a significant contribution becomes liable as a perpetrator of all the crimes in the JCE, Kvočka et al. Appeal Judgment, supra note 92, para. 99, see also M.J. Osiel, 'Modes of Participation in Mass Atrocities', 38 Cornell International Law Journal (2005) p. 799; Robinson, supra note 17, p. 940.

${ }^{101}$ Damgaard, supra note 24, p. 235 
are so grave, that such strict evidentiary requirements ought not to be relaxed.

On the other hand, based on the goal of international criminal law to bring the perpetrator to justice, it is argued that by nature of core international crimes, in most cases, strict evidential requirements will be impossible to satisfy and the heinous of such crimes, certain leeway ought to be given. Otherwise, many perpetrators of core international crimes will escape justice.

Then, the international criminal tribunals including the ICC are engaged in a very difficult balancing act. ${ }^{102}$ If the fundamental rights of the accused are in any way disrespected, the resulting damage to the international criminal law system in the long run could be substantial. In contrary, in accordance with international criminal law system, the fundamental rights of the accused must be respected, even if means that some of the perpetrators of core international crimes go unpunished.

Interestingly, the balancing test as such would relate to the question on legitimacy of the application of JCE in international criminal proceedings, which will be discussed below.

\subsection{What is the Legitimacy of the Application of JCE in International Criminal Proceedings?}

International criminal law and proceedings has matured rapidly in the past ten years, however, it still suffers from the questions about its legitimacy. Both the lack of democratic accountability and the significant amount of prosecutorial and judicial discretion inherent in the international criminal system compound this problem. ${ }^{103}$ In this section, a discussion on legitimacy of international criminal proceedings will be addressed, in particular, when the JCE applicability faces the questions on legitimacy because its application violates fundamental principle of human rights law, the principle of nullum crimen sine lege.

International criminal law is not embedded in a mature political or legal system that lends legitimacy to its criminal process as most of domestic criminal system does. Contemporary enforcement of international criminal law began only with the establishment of the ICTY and ICTR, which focuses individuals and its enforcement through terms of imprisonment. ${ }^{104}$ However, in general, one importance factor constitutes to the main reasons of international criminal justice is to spread of human rights doctrines and to

\footnotetext{
${ }^{102}$ Ibid., pp. 235 - 236.

103 A.M. Danner and J.S. Martinez, 'Guilty Associations: Joint Criminal Enterprise, Command Responsibility, and the Development of International Criminal Law', California Law Review 93 (2005) p. 96.

${ }^{104}$ Ibid.
} 
increase feeling that the most effective means of enforcing respect for such rights lies in prosecuting and punishing their violators. ${ }^{105}$ Regarding this, the one main goal of international criminal law is to bring to justice of perpetrators. To achieve such goal, the approaches must respect human rights law. ${ }^{106}$ As a result, the legitimacy is the condition for achieving not only the criminal law objectives, but also the human rights law's. The goals of both paradigms need to be balanced on a case-by-case basis.

To summarize, prosecution via JCE contravene the objectives of human rights law since it infringes upon the rights of the defendant, as it violates would be disrespect because it violates the principle of nullum crimen sine lege although the doctrine may achieve the international criminal law objectives. However, the legitimacy of the application of the doctrine of JCE in international criminal proceeding should be examined on a case-bycase basis by balancing the goals between international criminal law and human rights law paradigms.

\subsection{The test of the Application of JCE in the Prosecution}

As reason of international criminal justice to bring to justice, international criminal tribunals are important mechanisms for achieving such goal. However, in the same time, those tribunals are also tools for improving the protection of human rights in the proceedings. The human rights standards must be respected and applied by the tribunals through their cases. As a result, the prosecution before those tribunals must respect the various fair trial rights and the right to liberty as well as security of persons. ${ }^{107}$

According to international criminal law, the fundamental and basic principle that must be respected in the prosecution is the principle of legality (nullum crimen sine lege), which requires that a person may only found guilty in respect of acts constituted a violation of the law at the time of their commission. The maxim nullum crimen sine lege ("no crime without law") prescribes that an individual may be considered criminally responsible for conduct which unambiguously criminal at the time of its commissions.

\footnotetext{
105 A. Cassese, 'The Rationale for International Criminal Justice', in A. Cassese (ed.), The Oxford Companion to International Criminal Justice (Oxford University Press, New York, 2009) p. 123.

${ }^{106}$ An international criminal jurisdiction should adhere to internationally recognized human rights standard. Additionally, such standards regarding the rights of the accused be fully respected at all states of the proceedings, Report of the Secretary-General pursuant to Paragraph 2 of Security Council Resolution 808 (1993), UN Doc. S/25704, 3.5.1993 para. 106; Cryer et al., supra note 24, p. 353.

107 A. Zahar and G. Sluiter, International Criminal Law (Oxford University Press, New York, 2008) pp. $276-277$.
} 
The nullum crimen sine lege principle is referred as the principle of legality, which represents fundamental principles of criminal justice. ${ }^{108}$ This principle derives in part from a consciousness of the serious consequences which may flow the criminal process, and therefore of the need to protect relatively powerless individuals from the interference of State (or international State) machinery. ${ }^{109}$ The jurisprudence of the ad hoc tribunals always held that this principle applied both to the substance of specific international crimes as well as to various modes of individual criminal responsibility. ${ }^{110}$ Thus, the application of JCE before the tribunals must fully respect this principle.

This section intends to discuss the principle of nullum crimen sine lege in the context of the use of JCE as a tool for prosecuting the accused in international criminal proceedings.

\subsubsection{The Development of the Principle of nullum crimen sine lege}

The principle of nullum crimen sine lege originated in municipal law; its movement from being a principle primary of national law to being one clearly and firmly entrenched in international law was a product of WWII and its aftermath.

At the Nuremberg Tribunal, the principle of nullum crimen sine lege was repeatedly invoked by the defendants. The Tribunal characterized the doctrine as a 'general principle of justice'. ${ }^{111}$ According to this, the Tribunal held that the doctrine provided no defense to perpetrators of the crimes of aggression under international law. ${ }^{112}$ In addition, the doctrine as a principle of justice allowing the punishment of actions nor prescribed by law of their commission, when it would be 'unjust' for such wrongs to be 'allowed to go unpunished'. 113

The subsequence proceedings and other prosecutions by the Allies under CCL 10 in their respective zones of occupation, and domestic prosecution of Nazi; such as Israel prosecuted Adolf Eichmann in 1960, France prosecuted Klaus Barbie in 1988, Canada prosecuted Imre Finta in 1989 and other similar cases, the issue of nullum crimen sine lege were also revoked in the proceedings. However, those reached the same result by rejecting based on

\footnotetext{
${ }^{108}$ S. Lamb, 'Nullum Crimen, Nulla Poena Sine Lege in International Criminal Law', in A. Cassese, P. Gaeta \& J.R.W.D. Jones (eds.), The Rome Statute of International Criminal Court: A Commentary (Oxford University Press, New York, 2002) pp. 733 - 734.

${ }^{109}$ Ibid., p, 734.

${ }^{110}$ B. Swart, 'Modes of International Criminal Liability' in A. Cassese (ed.), The Oxford Companion to International Criminal Justice (Oxford University Press, New York, 2009) pp. $91-92$.

${ }^{111}$ Watkins \& DeFalco, supra note 12, p. 2.

112 Ibid.

${ }^{113}$ Lamb, supra note 108, p. 736.
} 
the Nuremberg jurisprudence, and no new arguments were adduced in support of that conclusion. ${ }^{114}$

Even though the pleas of nullum crimen sine lege were rejected by postWWII justice, the emergence of such principle as customary rule was due largely recognized by numerous multilateral and regional treaties in the post-WWII period. The Universal Declaration of Human Rights of 1948 (UDHR) is the first international instrument that gives independent recognition to the nullum crimen sine lege principle ${ }^{115}$ The principle was later reaffirmed in Article 15 of the International Covenant on Civil and Political Rights (ICCPR). ${ }^{116}$ Regarding international regulation of armed conflict, Article 99 of the Third Geneva Convention of 1949 and Article 6(c) of Additional Protocol II to the Geneva Convention of 1977 further prohibits prosecution under an ex post facto or retroactive law. Moreover, among regional human rights instruments, Article 7 of the European Convention on Human Rights of 1950 (ECHR), Article 9 of the American Convention on Human Rights of 1969 and Article 7(2) of the African Charter of Human and People's Rights, all contain a prohibition against retroactivity.

\subsubsection{Testing the Legality of the principle of nullum crimen sine lege}

According to the ICTY jurisprudence in the Hadžihasanović Case, the Chamber focused on the actual conduct of the accused at the time of commission and held that:

'In order to meet the principle of nullum crimen sine lege, it must only be foreseeable and accessible perpetrator that his concrete conduct was punishable at the time of commission. Whether his conduct was punishable as an act or an

\footnotetext{
${ }^{114}$ See ibid., pp. $735-739$.

${ }^{115}$ Universal Declaration of Human Rights, 10 December 1948, GA Res 217A (III), UN Doc A/811 (1948), Art. II(2) states that:

"[n]o-one shall be held guilty of any...offence on account of any act or omission which did not constitute a criminal offence, under national or international law, at the time when it was committed. Nor shall a heavier penalty be imposed than the one that was applicable at the time the...offence was committed"

${ }^{116}$ Art. 15(1) of the ICCPR states that:

'[n]o one shall be held guilty of any criminal offence on account of any act or omission which did not constitute a criminal offence, under national or international law, at the time when it was committed. Nor shall a heavier penalty be imposed than the one that was applicable at the time when the criminal offence was committed. If, subsequent to the commission of the offence, provision is made by law for the imposition of the lighter penalty, the offender shall benefit thereby.'
}

Art. 15(2) states that:

"[n]othing in this article shall prejudice the trial and punishment of any person for any act or omission which, at the time when it was committed, was criminal according to the general principles of law recognized by the community of nations." 
omission, or whether the conduct may lead to criminal responsibility, disciplinary responsibility or other actions are not of material importance'. ${ }^{117}$

Due to this, there are two sets of questions arise in relation to the application of the principle of nullum crimen sine lege in the context of the application of JCE namely: (i) question on the existence of the law and (ii) the question relates to the foreseeability and accessibility requirements.

\subsubsection{The Existence of the Law}

The first inquiry in applying the claim of nullum crimen sine lege is whether the legal principle being challenged existed at the relevant time. Thus, the first condition for applying JCE before the tribunal is whether the mode of liability of JCE was punishable at the time that the crimes were committed under international law or domestic law. To analyse this inquiry requires an analysis not only domestic law at the relevant time but also international law. Then, the law from all traditional sources of international law as laid out in Article 38(1) of the Statute of the International Court of Justice (ICJ); international conventions, international custom, general principles of law as well as judicial decisions and the teaching of the most highly qualified publicists, must be taken into account. Even if the challenged law has evolved since the relevant time, it may still be applied in its current form if the fundamental interests of justice such as the principle of nullum crimen sine lege as safeguarded. ${ }^{118}$

\subsubsection{Foreseeability and Accessibility Requirement}

In considering the principle of nullum crimen sine lege, apart from the existence of the law, a court must be satisfied that the applicable criminal responsibility was foreseeable and accessible at the relevant time. ${ }^{119}$ In order to the foreseeability and accessibility, the requirement will be met if it can be shown that it would be foreseeable and accessible to a possible perpetrator that his concrete conduct was punishable at the time of commission.

According to the ICTY jurisprudence, the foreseeability must be sufficient; the law not only that existed at the relevant time, but also that such existence was in a form specific enough to make liability foreseeable to the accused when acting. ${ }^{120}$ Similarly, the accessibility must be sufficient at the relevant time to the specific accused. ${ }^{121}$ Furthermore, the jurisprudence of ad hoc tribunals has been to presume that both requirements were met if the conduct was found to be punished under international law. ${ }^{122}$

\footnotetext{
${ }^{117}$ Prosecutor v. Enver Hadžihasanović, Mehmed Alagic and Amir Kubura, 12 November 2002, ICTY, Decision of Joint Challenge to Jurisdiction. Case No. IT-01-47-PT, para. 62.

${ }^{118}$ Watkins \& DeFalco, supra note 12, p. 4.

${ }^{119}$ Ojdanić's JCE Decision, supra note 27, para. 37.

${ }^{120}$ Ibid.

${ }^{121}$ Ibid., para 21.

122 Duch Case, Criminal Case File No. 001/18-07-2007-ECCC/OCIJ (PTC 02), ECCC, Amicus Curiae Brief Submitted by the Centre for Human Rights and Legal Pluralism,
} 
The Chamber in Milutinović et al. Case at the ICTY found the elements of accessibility that this requirement will be fulfilled, if each of the three factors are addressed; (i) parallel modes of liability in domestic law; (ii) state practice and other sources of international law; and (iii) the inherent culpability of the acts of the accused. ${ }^{123}$

\section{(i) Parallel Modes of Liability in Domestic Law}

According to Milutinović et al. Case, the Appeal Chamber states that domestic legal parallel to JCE, although not necessary conclusive of foreseeability or accessibility, are highly probative. ${ }^{124}$ For example, the Chamber found that "many domestic jurisdiction...provide for" form of "liability under various names" sufficiently similar to JCE that such forms "run parallel to custom"125 Regarding this the important question is whether the domestic jurisdiction of the accused provides for liability similar to JCE $?^{126}$

Moreover, the Chamber found that Article 26 of the Criminal Code of the Federal Republic of Yugoslavia in force at the relevant time did provide for criminal liability for the foreseeability acts of others in terms strikingly similar to those used to define [JCE]. ${ }^{127}$ As a result, the segment of Criminal Code and similar provision in the penal law of other states provided notice to the accused that he could be held liability under JCE for his specific acts in a form undeniably accessibility to him. ${ }^{128}$

\section{(ii) State Practice and Other Sources of International Law}

The ICTY jurisprudence in the Milutinović et al. Case recognised that "rules of customary law may provide sufficient guidance as to [...] standard[s,] the violation of which could entail criminal liability." "129 Thus, if there is sufficient evidence of a rule of customary international criminal law available to the accused, there need not be any parallel domestic legislation. For example, the Milutinović et al. Case, the Chamber found that at the relevant time there existed "a long and consistent stream of judicial decisions, international instruments and domestic legislation" cited in the Tadic Appeal Judgment, which put the accused on notice of the existence of

McGill University, 27 October 2008 ['McGill's amicus curiae brief'], para. 82; see Prosecutor v. Milan Martić, 8 October 2008, ICTY, Judgment on Appeal - Separate Opinion of Judge Schomburg on the Individual Criminal Responsibility of Milan Martić, Case No. IT-95-11-A.

${ }^{123}$ Ojdanić's JCE Decision, supra note 27, para. 43; see also Watkins \& DeFalco, supra note 12, pp. $69-71$.

${ }^{124}$ Ojdanić's JCE Decision, supra note 27, para. 41.

125 Ibid., para. 43.

${ }^{126}$ Ibid., para. 40.

127 Ibid.

${ }^{128}$ Ibid., para. 41.

${ }^{129}$ Watkins \& DeFalco, supra note 12, p. 70. 
JCE as a mode of liability and allowed him the opportunity to 'regulate his conduct accordingly' in order to avoid criminal responsibility. ${ }^{130}$

Due to the "lack of any written norms or standards," international criminal tribunals "often rely upon the atrocious nature of the crimes charged to conclude that the perpetrator of such an act must have known that he was committing a crime. ${ }^{131}$ The Milutinović et al. Case ${ }^{132}$ states that:

"the immorality or appalling character of an act is not a sufficient factor to warrant its criminalization [...] under customary international law, it may in fact play a role in that respect, insofar as it may claim by the Defence [...] that it did not know of the criminal nature of the acts"

While JCE liability is simple mode of liability for imputing separate, substantive crime, the Appeals Chamber in the Tadic Case noted that liability via participation in a JCE does nothing to lessen or even modify the moral culpability of the accused. ${ }^{133}$ Thus, although JCE is not an offense in itself, actively participating in a criminal enterprise associated with the commission of international crimes is often inherently culpable enough to put on notice of the illegality of his actions at the relevant time. ${ }^{134}$

According to abovementioned, testing the legality of the application of JCE in the prosecution before international criminal tribunals must respect the principle of nullum crimen sine lege. Thus, the tribunal will be able to apply the JCE, if that case fulfills satisfy each of two requirements pursuant to the principle of nullum crimen sine lege: the existence of the law requirement and the foreseeability and accessibility requirements.

To sum up, this chapter gives the conceptual framework of the doctrine of JCE in the context of international criminal law, which its application would be in accordance with the human rights standards. As questions on the legality and legitimacy, the analysis in this chapter will be used to answer these questions. Before examining these questions in the ECCC, the chapter that follows will give a brief historical background of the Khmer Rouge trials, the establishment of ECCC, its jurisdiction and its tools for prosecuting the former senior leaders for the crimes committed during the Democratic Kampuchea regime.

\footnotetext{
${ }^{130}$ Ibid.; see Tadić Appeal Judgment, supra note 3, paras. 195 - 229.

131 Ojdanić's JCE Decision, supra note 27, para. 41. cited in Watkins \& DeFalco, supra note 12 , p. 70

132 Ibid., para. 42.

133 Tadić Appeal Judgment, supra note 3, para 191 states that "the moral gravity of [JCE] participants is often no less - or indeed no different - form that of those actually carrying out the acts in question".

${ }^{134}$ Watkins \& DeFalco, supra note 12, p. 71
} 


\section{The Khmer Rouge Trials and the ECCC}

\subsection{Historical Background}

The purpose of this section is to examine the approach of prosecution for the Khmer Rouge crimes committed during 1975 to 1979 in Cambodia then, the historical background of the Cambodia and the Khmer Rouge role in Cambodia during the Democratic Kampuchea regime in 1970s would be a useful part for understanding the case.

The conflict in Cambodia took place between 17 April 1975 and 7 January 1979. It was primarily an internal conflict led by a Maoist insurrectional group named the Khmer Rouge. The Khmer Rouge forces entered Phnom Penh on 17 April 1975, establishing the state of Democratic Kampuchea. The Khmer Rouge was headed by Pol Pot, or 'Brother Number One' (formerly known as Saloth Sar), who joined the communist ranks while being a student in Paris in the early 1950s. The Khmer Rouge reign ended when, on 7 January 1979, Vietnamese troops entered Phnom Penh. However, it continued fighting a guerrilla war with significant foreign support against the new government for another decade. ${ }^{135}$ During 19751979, estimated 1.5 million persons were killed or created conditions leading to the death by the Khmer Rouge regime. ${ }^{136}$

The years of Khmer Rouge were marked by abuses of individual and group human rights on an immense and brutal scale. The crimes were committed during the Khmer Rouge regime can be grouped into four categories, which each category of crimes contains serious offenses under international law and domestic law:

(i) the evacuation of the cities and towns;

(ii) forced labour and inhumane living conditions;

(iii) attacks on enemies of the revolution, that is, officials of the prior regime, ethnic minorities, teacher, student and other educated elements, and religious leaders and institutions; and purges within the party. ${ }^{137}$

Ultimately, Cambodia's civil war came to the end after signing the 1991 Paris Accords. Nevertheless, over a decade later, not a single member of the

\footnotetext{
${ }^{135}$ Ratner, supra note 5, p. 613.

${ }^{136}$ M.C. Bassiouni, Introduction to International Criminal Law (Transnational Publishers, New York, 2003) p. 548

137 See S.R. Ratner, J.S. Abrams and J.L. Bischoff, Accountability for Human Rights Atrocities in International Law: Beyond the Nuremberg Legacy, $3{ }^{\text {rd }}$ eds. (Oxford University Press, New York, 2009) pp. 308 - 312.
} 
Khmer Rouge has been prosecuted for their acts in the 1970s until the 1990s that the UN became involved with Cambodia. ${ }^{138}$

\subsection{The Khmer Rouge Trials before the ECCC}

It is clear that the Khmer Rouge committed serious crimes under international and domestic law. Hence, there is the need to bring those Khmer Rouge officials to justice. This section will examine the efforts to hold accountable those who committed crimes during the Khmer Rouge regime since the Khmer Rouge fled power in 1976 until the establishment of the ECCC.

The attempt to hold Khmer Rouge officials accountable for their actions during they in reign began in 1979. The trial of Pol Pot and Ieng Sary for the crime of genocide was held in Phnom Penh, Cambodia, in August 1979, which was the first trial of government leader under the Genocide Convention. The trial was conducted under the support of new government. Nevertheless, this trial was conducted in a political context, hence termed as a show trial; the two defendants were tried in absentia and the suggestion is the proceedings were held not to attain justice, but to create guilt for show. ${ }^{139}$

The materialized effort at accountability in bringing the Khmer Rouge officers to justice was done in mid 1990s when the Paris Accords were negotiated. ${ }^{140}$ While the 1991 Paris Accords were being negotiated in order to end the Cambodian civil war, outside states felt that Khmer Rouge participation was essential, and consequently no suggestions of accountability were raised. ${ }^{141}$ After 11 rounds of negotiation, the Paris Agreement, signed on 23 October 1991, put a peace plan into place that involved the government of Vietnam setting up the People's Republic of Kampuchea, and Cambodia's rival factions, including the dominant Khmer Rouge. The Paris Agreement called for the creation of the UNTAC. Its mission was to organise and conduct elections while maintaining peace and political neutrality.

In 1997, the UN Special Representative for Human Rights in Cambodia, Thomas Hammarberg of Sweden, forced the new government to consider the impunity question. In June 1997, the Cambodian government asked the UN to assist in bringing to justice members of the Khmer Rouge for the

\footnotetext{
138 Ibid.

${ }^{139}$ H.J. de Nike, 'Reflections of a Legal Anthropologist on the Trial of Pol Pot and Ieng Sary' in H.J. de. Nike, J. Quigley and K.J. Robinson (eds.), Genocide in Cambodia: Documents from the Trial of Pol Pot and Ieng Sary (University of Pennsylvania Press, Philadelphia, 2000) p. 20.

${ }^{140}$ Ratner, supra note 5, p. 613.

141 A.J. Buckley, 'The Conflict in Cambodia and Post-Conflict Justice' in M.C. Bassiouni (ed.) Post-Conflict Justice (Transitional Publishers, New York, 2002) pp. 646 - 647.
} 
atrocities they committed during 1975-1979. ${ }^{142}$ As a result, the UN Secretary-General, Kofi Annan, appointed the Group of Experts for Cambodia, in 1998. After nine months the Group issued a report in February 1999 detailing the evidence of the crimes committed, evaluating the evidence under existing international and Cambodian criminal law, assessing the prospects of bringing the Khmer Rouge to justice, and most importantly, evaluating the options for accountability. ${ }^{143}$

Group of Experts considered five options for an accountability mechanism including: fully domestic trials under Cambodian law, a tribunal established by the UN, a mixed tribunal under UN administration, an international tribunal established by treaty, and trials in states other than Cambodia under their domestic law. ${ }^{144}$ The Group recommended the second option of a new ad hoc UN tribunal but Hun Sen, the Cambodian Prime Minister, rejected their proposal. The UN continued to engage the Cambodian government in negotiations with the hope of bringing the Khmer Rouge leaders to justice. Consequently, in January 2001, the UN and Cambodia achieved a clumsy compromise, with the encouragement of the US, on the mixed UNCambodian tribunal. On 10 August 2001, the Cambodian National Assembly adopted the ECCC Law. ${ }^{145}$

The ECCC Law and the 2004 Agreement between the UN and the Royal Government of Cambodia Concerning the Prosecution under Cambodian Law of Crimes Committed during the Period of Democratic Kampuchea together established the ECCC as a special court in Cambodia requiring the participation of international judges, prosecutors, and administrators in the ECCC alongside their Cambodian counterparts.

\subsection{Jurisdiction of the ECCC}

This section will investigate the jurisdiction of the ECCC; ratione temporis, ratione personae and ratione materiae, as set out in the ECCC Law. Due to the principle of nullum crimen sine lege, it requires that a person may only be found guilty in respect of acts constituted a violation of the law at the time of their commission. Then, the jurisdiction of the ECCC must remains within the crimes that were crimes under international and national law when the Khmer Rouge seized power in 1975.

\footnotetext{
${ }^{142}$ Ibid., p. 647; see a letter dated June 21, 1997 from the First and Second Prime Minister of Cambodia addressed to the Secretary-General, in Identical letter dated June 23, 1997 form the Secretary-General addressed to the President of the General Assembly and to the President of the Security Council, June 24, 1997, U.N. Doc. A/51/930-S/1997/488.

${ }^{143}$ Ratner, supra note 5, p. 614.

${ }^{144}$ Ibid., pp. 613 - 614.

${ }^{145}$ See Buckley, supra note 141, pp. 646 - 653.
} 


\subsubsection{Ratione Temporis Jurisdiction}

The purpose of the establishment of the ECCC is to bring the Khmer Rouge senior leaders and those most responsible to justice for the atrocities they committed during the Khmer Rouge regime. Thus, the ECCC has ratione temporis jurisdiction (temporal jurisdiction) of crimes that were committed during the period from 17 April 1975 to 6 January 1979, corresponding to the main period of Democratic Kampuchea and the reign of the Khmer Rouge. ${ }^{146}$ Pursuant to this, the ECCC has jurisdiction over those crimes, which were committed during such period.

The temporis jurisdiction of the ECCC has been expressly stipulated in General Provision of the ECCC Law, Article 1 reads: "[t]hat were committed during the period from 17 April 1975 to 6 January 1979.” and has been repeated in the provisions regarding the competence of the ECCC in Article 2 to Article 8 of the ECCC Law.

\subsubsection{Ratione Personae Jurisdiction}

The individuals who may be investigated and prosecuted before the ECCC constitute a narrow set of alleged perpetrators: the "senior leaders of Democratic Kampuchea and those who were most responsible" for the crimes falling within the subject matter jurisdiction of the Chambers. This small set of individuals reflects the original purpose of the ECCC, which always has been to investigate and bring to justice the top leadership in the Pol Pot regime and notorious atrocity lords of the period. It also reflects the limited capacity and resources of the ECCC to undertake investigative and trial work.

The ECCC Law provides personae jurisdiction (personal jurisdiction) in the purpose of the Law in Article 1 as General Provision that:

\footnotetext{
"The purpose of this law is to bring to trial senior leaders of Democratic Kampuchea and those who were most responsible for the crimes and serious violations of Cambodian penal law, international humanitarian law and custom, and international conventions recognized by Cambodia, that were committed during the period from 17 April 1975 to 6 January 1979”.
}

However, the death of two Khmer Rouge leaders namely, Pol Pot, the highest senior leader of Khmer Rouge who died in April 1998 and Ta Mok, who died on 21 July 2006, means that two probably most responsible will never stand trial. However, several former leaders are living quietly in Cambodia. Only one is in detention.

However, in July 2007, the Co-Prosecutors submitted a list of five indicted persons to the Co-Investigating Judges and requested that they be indicted and brought to trial. These five indicted persons include (i) Kiang Guek

${ }^{146}$ See Article 1 to Article 8 of the ECCC Law. 
Eav alias Duch, the former commandant of the main torture house, Tuol Sleng; (ii) Ieng Sary, the former Deputy Prime Minister in Foreign Affairs; (iii) Ieng Thirith, the former Minister of Social Affairs; (iv) Nuon Chea, the movement's chief ideologue; and (v) Kheiu Samphan. Consequently, the five persons have been charged within the jurisdiction of the ECCC.

\subsubsection{Ratione Materiae Jurisdiction}

The ECCC has ratione materiae jurisdiction (subject matter jurisdiction) over crimes and serious violations of Cambodian penal law, international humanitarian law and custom, and international conventions recognized by Cambodia, that were committed during the period from 17 April 1975 to 6 January 1979.

According to the ECCC Law, the ECCC has jurisdiction for prosecuting all suspects who committed any of these crimes set forth in the 1956 Penal Code, genocide, crimes against humanity, and grave breaches of the 1949 Geneva Conventions. ${ }^{147}$

Furthermore, the ECCC may exercise jurisdiction over the destruction of cultural property during armed conflict under the 1954 Hague Convention for Protection of Cultural Property in the Event of Armed Conflict, as well as of crimes against internationally protected persons pursuant to the 1962 Vienna Convention on Diplomatic Relations. ${ }^{148}$

\section{(i) Genocide}

Cambodia has been a party to the 1948 Convention on the Prevention and Punishment of the Crime of Genocide (Genocide Convention), without reservation, since 1951 when the Convention entered into force. The Khmer Rouge never denounced the Genocide Convention when they were in power. Thus, there is no nullum crimen sine lege obstacle in the crime of genocide in the competence of the ECCC.

According to Article II of the Genocide Convention, an act to be defined as genocide are: (i) an act committed with the intent to destroy, in whole or in part, one of these groups as such, (ii) an act against a national, ethnical, racial or religious group, and (iii) killing; causing serious bodily or mental harm; deliberately inflicting conditions of life calculated to bring about physical destruction; imposing measures intended to prevent births; or forcibly transferring children from the group. ${ }^{149}$

${ }^{147}$ See Article 3 new to Article 6 of the ECCC Law.

${ }^{148}$ Article 7 and Article 8 of the ECCC Law.

${ }^{149}$ Genocide Convention Article II reads that:

"In the present Convention, genocide means any of the following acts committed with intent to destroy, in whole or in part, a national, ethnical, racial or religious group, as such: 
During the regime, the Khmer Rouge committed acts of genocide against the Cham minority group, the Buddhist monkhood, as well as the Vietnamese, Chinese and Thai communities. These groups clearly qualify as protected groups under the Genocide Convention: the Cham as an ethnic and religious group; the Vietnamese, Chinese and Thai communities as ethnic and, perhaps, racial groups; and the Buddhist monkhood as a religious group. ${ }^{150}$

Thus, the Khmer Rouge subjected the people of Cambodia to almost all of the acts enumerated in Article II (a) through (e) of the Genocide Conventions well as stating in Article 4 of the ECCC during their rule. ${ }^{151}$

Article 4 of the ECCC Law states on the competence of the Court that the Court has jurisdiction over the crimes of genocide as defined in the Genocide Convention, which were committed during the Khmer Rouge regime. Moreover, the ECCC Law also provides that the punishable acts are attempts to commit acts of genocide, conspiracy to commit acts of genocide and participation in acts of genocide. ${ }^{152}$

\footnotetext{
(a) Killing members of the group;

(b) Causing serious bodily or mental harm to members of the group;

(c) Deliberately inflicting on the group conditions of life calculated to bring about its physical destruction in whole or in part;

(d) Imposing measures intended to prevent births within the group;

(e) Forcibly transferring children of the group to another group.”
}

${ }^{150}$ Ratner, Abrams and Bischoff, supra note 137, pp. 320 - 321.

${ }^{151}$ Ibid., p. 320

152 ECCC Law Article 4 provides that:

"The Extraordinary Chambers shall have the power to bring to trial all Suspects who committed the crimes of genocide as defined in the Convention on the Prevention and Punishment of the Crime of Genocide of 1948, and which were committed during the period from 17 April 1975 to 6 January 1979.

The acts of genocide, which have no statute of limitations, mean any acts committed with the intent to destroy, in whole or in part, a national, ethnical, racial or religious group, such as:

- $\quad$ killing members of the group;

- causing serious bodily or mental harm to members of the group;

- deliberately inflicting on the group conditions of life calculated to bring about its physical destruction in whole or in part;

- $\quad$ imposing measures intended to prevent births within the group;

- forcibly transferring children from one group to another group.

The following acts shall be punishable under this Article:

- $\quad$ attempts to commit acts of genocide;

- $\quad$ conspiracy to commit acts of genocide;

- $\quad$ participation in acts of genocide.” 
The Khmer Rouge atrocities committed crimes against humanity against hundreds of thousands of people during the Democratic Kampuchea had the control over Cambodia; cases of murder (rising to the level of extermination of political opposition), forced labour, torture, imprisonment, and other inhumane acts. ${ }^{153}$ Moreover, the evidence regarding forcible transfers of population shows a cruel and unlawful means of accomplishing the plan, as well as an unjustifiable purpose aimed against the city-dwellers. ${ }^{154}$

According to Article 5 of the ECCC Law, the Court has ratione materiae jurisdiction over crimes against humanity, which are any acts committed as part of a widespread or systematic attack directed against any civilian population, on national, political, ethnical, racial or religious grounds, such as: murder; extermination; enslavement; deportation; imprisonment; torture; rape; persecutions on political, racial, and religious grounds; and other inhumane acts. ${ }^{155}$

\section{(iii) War Crimes}

The Khmer Rouge regime was involved in warfare with neighbouring States, and a significant number of atrocities were committed in this context. ${ }^{156}$ Cambodia, as well as Vietnam, Thailand and Laos were parties to the 1949 Geneva Conventions during such period, and were therefore obliged to abide by the grave breaches provisions, as well as the additional criminality under the then customary law. ${ }^{157}$

In order to Article 6 of the ECCC Law, the Court has ratione materiae jurisdiction to bring to trial all suspects who committed or ordered the commission of grave breaches of the Geneva Conventions of 12 August 1949, such as wilful killing; torture or inhumane treatment; wilfully causing great suffering or serious injury to body or health; destruction and serious damage to property, not justified by military necessity and carried out unlawfully and wantonly; compelling a prisoner of war or a civilian to serve in the forces of a hostile power; wilfully depriving a prisoner of war or civilian the rights of fair and regular trial; unlawful deportation or transfer or unlawful confinement of a civilian; and taking civilians as hostages, against persons or property protected under provisions of these Conventions, and which were committed during the ratione temporis jurisdiction. ${ }^{158}$

\footnotetext{
153 Ratner, Abrams and Bischoff, supra note 137, p. 324.

154 Ibid., p. 325; see also Report of the Group of Experts for Cambodia established pursuant to General Assembly resolution 52/135, UN GAOR, 53th Sess., UN Doc.S/1999/231 \& A/53/850 (1999) [ 'Report of the Group of Experts'], para. 67.

155 See Article 5 of the ECCC Law.

${ }^{156}$ Report of the Group of Experts, supra note 154, para. 72.

${ }^{157}$ Ibid., para. 73.

${ }^{158}$ See Article 6 of the ECCC Law.
} 
The Khmer Rouge's destruction of cultural property is well documented. As part of their systematic attack upon Buddhism, the Khmer Rouge desecrated or destroyed most of the country's 3,000 pagodas, inflicting irreparable damage on statues, sacred literature, and other religious items. ${ }^{159}$ Similar damage was inflicted on mosques of the Cham people. The regime also attacked Christian places of worship, even disassembling the Cathedral of Phnom Penh stone by stone until only a vacant lot remained. ${ }^{160}$

Moreover, the Khmer Rouge leaders and cadre appear to have committed at least one other crime on a far smaller scale - crimes against internationally protected persons. In April 1975, the regime detained personnel in the French embassy and then removed and murdered Cambodian husbands of foreign diplomatic personnel. ${ }^{161}$

According to the ECCC Law, the ECCC has the jurisdiction over international crimes incurring individual criminal responsibility. The ECCC shall have the power to bring to trial all suspects most responsible for the destruction of cultural property during armed conflict pursuant to the 1954 Hague Convention for Protection of Cultural Property in the Event of Armed Conflict and crimes against internationally protected persons pursuant to the Vienna Convention of 1961 on Diplomatic Relations, which were committed during the period or Khmer Rouge regime. ${ }^{162}$

\section{(v) Crimes under Cambodian Law}

Remaining in accordance with the principle of nullum crimen sine lege, the Cambodian Law on which the ECCC would base their competence would have to be the domestic laws in force in 1975. The primary source of criminal law prior to the Khmer Rouge period is the 1956 Penal Code (Pénal et Lois Pénales), published by the Ministry of Justice of the Kingdom of Cambodia, though it appears that no sources reliably and comprehensively update this law through 1975. As for subsequent law that might govern the Khmer Rouge years, Democratic Kampuchea appears to have published none. No secondary sources on Cambodian criminal law appear extant. $^{163}$

The 1956 Penal Code represents, as pre-1975 Cambodian criminal law, covers the primary crimes recognised by most states namely: homicide, torture, rape, other physical assaults, arbitrary arrest or detention, attacks on religion, other abuses of government authority and related crimes. ${ }^{164}$

\footnotetext{
${ }^{159}$ Ratner, Abrams and Bischoff, supra note 137, p. 328.

160 Ibid., p. 329.

${ }^{161}$ Report of the Group of Experts, supra note 154, para. 79.

${ }^{162}$ See the ECCC Law Articles 7 and 8.

163 Report of the Group of Experts, supra note 150, para.

${ }^{164}$ Ratner, Abrams and Bischoff, supra note 137, pp. 335-338.
} 
However, the crimes specified in Article 3 of the ECCC Law as relevant to the Chambers under the 1956 Penal Code of Cambodia are homicide, torture, and religious persecution, which were committed during the period from 17 April 1975 to 6 January 1979. These being crimes under a domestic law, the Prosecutor would not need to convince the Chambers of the additional elements required for international offences. ${ }^{165}$

\subsection{Individual Criminal Responsibility under ECCC Law}

Generally, it is recognised that the principle of nullum crimen sine lege must be respected in international criminal law and in every state of international criminal proceedings. This implies that the act of the accused must have constituted an international crime at the time he performed the act and the prohibition is sufficiently clear and precise as to enable the accused to know what it details that the accused was able to be aware of its existence. The ad hoc tribunals always held that this principle not only applies to specific international crimes but equally to the various mode of individual criminal responsibility. Thus, the application of the modes of individual criminal responsibility, including JCE, at the ECCC must respect the principle as such. This section intends to consider the prosecutorial tools in the prosecution before the ECCC in accordance with its Law.

International criminal law has long recognized that persons are responsible for acts even if they did not directly commit them. This principle has appeared in various instruments that declare individuals responsible if they plan, instigate, order, aid or abet, or conspire to commit the crimes. ${ }^{166}$

According to the ECCC Law, the principle of individual criminal responsibility is laid down in Article 29 of the ECCC Law, which states that:

"Any Suspect who planned, instigated, ordered, aided and abetted, or committed the crimes referred to in article 3 new, 4, 5, 6, 7 and 8 of this law shall be individually responsible for the crime..."

The provision of Article 29 mirrors Article 7 (1) of the ICTY Statute, which is explained by the Report of the Secretary-General on the establishment of the ICTY, which states the following:

"An important element in relation to the competence ratione personae (personal jurisdiction) of the International Tribunal is the principle of individual criminal responsibility. As noted above, the Security Council has reaffirmed in a number of

165 See Article 3 new of the ECCC Law.

${ }^{166}$ See, e.g., Charter of Nuremberg Tribunal, Article 6 (a); CCL.10, Article II (2); Genocide Convention, Article III; Statute of the ICTY, Article 7 (1); Statute of the ICTR, Article 6 (1); 1996 Draft Code of Crimes Against the Peace and Security of Mankind, Article 2 (3); Rome Statute of the ICC, Article 25. 
resolutions that persons committing serious violations of international humanitarian law in the former Yugoslavia are individually responsible for such violations" 167

The ECCC Law, Article 29 sets out the parameters of personal criminal responsibility under its Law. Thus, any act falling under one of the five categories contained in the provision: planning; instigating; ordering; aiding and abetting; and committing, may entails the criminal responsibility of the perpetrator or whoever has participated in the crime in one of the ways specified in the provision.

Moreover, currently, the ambit of individual criminal responsibility according to the ECCC Law has been questioned that whether JCE liability is a tool in the prosecution in the ECCC legal regime by falling within the ambit of 'committing' under Article 29 of the ECCC Law. This is one of the jurisprudential concerns I intend to discuss in Chapter 4.

To summarize, the ECCC was established for prosecuting the former Khmer Rouge senior leaders who committed core crime under the Khmer Rouge regime. The ECCC has jurisdiction over genocide, crime against humanity, war crimes and crimes under Cambodian law which were committed during the period from 17April 1975 to 6 January 1979. Moreover, the ECCC has jurisdiction to bring to justice any person not only person who committed the crimes, but also person who planned, instigated, ordered or aided and abetted the crimes pursuant to its Law. In Chapter 4, the thesis will focuses on the ECCC and its application of the doctrine of JCE liability against the accused In particular, the discussion analyses the legality and legitimacy of the application of JCE.

167 Report of the Secretary-General Pursuant to Paragraph 2 of Security Council Resolution 808 (1993), U.N. Doc. S/25704, 3 May 1993 ['Report of the SecretaryGeneral'], para. 53. 


\section{JCE Applicability and the ECCC}

As examined in Chapter 2 and 3 above regarding the doctrine of JCE in the international criminal law context and the ECCC, JCE is not a kind of crimes but it is a method by which crimes can be committed. In a JCE, a group of people agree to act together to accomplish an illegal purpose. Each member of the group that agrees to accomplish the illegal purpose and commits a significant act to advance the illegal purpose is a participant of a criminal enterprise. With JCE, the accused can be convicted of all the crimes committed in furtherance of the joint criminal purpose.

Concerning cases at the ECCC, the Co-Prosecutors have attempted to apply the doctrine of JCE for charging and prosecuting the five former Khmer Rouge senior leaders namely: Duch, Ieng Say, Ieng Thirith, Nuon Chea, and Khieu Samphan, for the crimes committed during the Democratic Kampuchea regime 1975-1979 168

This chapter concerns one of the most important and difficult modes of liability in international criminal law used before the ECCC, JCE liability, which has become a problematic and controversial tool in the prosecution before the ECCC. Thus, this chapter intends to discuss the use of JCE as a prosecutorial tool before the ECCC as well as the legality and legitimacy of the application of such tool.

\subsection{Procedural Background}

The issue of individual criminal responsibility under the doctrine of JCE was brought to the ECCC by Ieng Sary in his Motion against the application of JCE at the ECCC distributed to the OCIJ on 28 July 2008. ${ }^{169}$ This Motion was filed to the OCIJ because the OCP intended to apply JCE doctrine before the ECCC as reflected in its public press release, wherein it noted that the alleged crimes reference in the Introductory Submission that:

\footnotetext{
"Pursuant to their preliminary investigations, the Co-Prosecutors have identified and submitted for investigation twenty-five distinct factual situations of murder, torture, forcible transfer, unlawful detention, forced labor and religious, political and ethnic persecution as evidence of the crimes committed in the execution of this common criminal plan." 170
}

Due to the Motion, Ieng Sary gave four main reasons of inapplicability of JCE before the ECCC namely: (1) it not specified in the ECCC Law; (2) it is

\footnotetext{
${ }^{168}$ Appeal on Closing Order, supra note 11, paras. $11-12$.

${ }^{169}$ See generally JCE Motion, supra note 7.

${ }^{170}$ See Press Release, Statement of the Co-Prosecutors, 18 July 2007, p. 4; emphasis added by author.
} 
not part of Cambodian law in relevant time; (3) it is not customary international law in relevant time; and (4) it is not recognised by an international convention enforceable at the ECCC. As a result, applying the doctrine JCE at the ECCC would violate the principle nullum crimen sine lege. ${ }^{171}$ Hence, he requested the Office of Co-Investigating Judges to declare that JCE liability is not a form of liability applicable before the ECCC. ${ }^{172}$

After that, the issue of JCE liability has been applied in the case against Duch, the first accused of the ECCC, where the Co-Prosecutors found that the Co-Investigating Judges had committed two errors of law according to their Closing Order on 8 August 2008. First, they failed to indict Duch for the commission of the national crimes of homicide and torture as defined by the 1956 Penal Code and punishable under Article 3 of the ECCC Law and the second error, the judges failed to indict Duch for the commission of crimes through his participation in a JCE. ${ }^{173}$ Then, on 5 September 2008, the Co-Prosecutors appealed against the Closing Order of the CoInvestigating Judges on those two grounds. ${ }^{174}$

On the second ground, JCE, the Co-Prosecutors submitted their appeal that the JCE should be applied at the ECCC because it more accurately reflects the responsibility of participants in international crimes than other forms of liability and captures conduct which might not fit under other forms of liability. In addition, the application of JCE at the ECCC would not violate the principle of nullum crimen sine lege. ${ }^{175}$

Following such appeal, the question regarding the doctrine of JCE and the ECCC has become a controversial issue in the ECCC as well as among international criminal lawyers. ${ }^{176}$ The ambiguous question of whether JCE can be applied before the ECCC, taking into account the fact that the crimes were committed during the period 1975-1979, has been a significantly debatable issue within the international community.

On 5 December 2008, the PTC made the decision on the appeals of the OCP and decided to dismiss the appeal on the ground of JCE. In the view of the PTC's reasoning and conclusion, it is not necessary to determine the question of customary international law status of JCE at the relevant time (1975-1979). It is similarly not necessary to determine the applicability of

\footnotetext{
${ }^{171}$ JCE Motion, supra note 7. p. 1.

${ }^{172}$ Ibid., p.15.

${ }^{173}$ Closing Order, supra note 10, paras. 153 - 161.

${ }^{174}$ Appeal on Closing Order, supra note 11, paras. $11-12$.

${ }^{175}$ Ibid., paras. 49, 57.

176 The PTC invited three international criminal law scholars; Professor Antonio Cassese, Professor Kai Ambos and the Centre for Human Rights and Legal Pluralism of McGill University to submit written amici curiae briefs on two issues regarding the JCE doctrine; the development of the theory of JCE and the evolution of the mode of liability, with particular reference to the time period 1975-1979; and whether JCE as a mode of liability can be applied before the ECCC, taking into account the fact that the crimes were committed in the period 1975-1979, see Amicus Curiae Invitations, supra note 12.
} 
JCE, as opposed to other forms of liability under Cambodian law, before the ECCC. ${ }^{177}$

However, on 8 December 2009 in the case against Ieng Sary, the CoInvestigating Judges issued a decision ruling that all three categories can be applied against all accused. ${ }^{178}$ In addition, the Co-Investigating Judges find that there is a basis under international law for applying actus reus and mens rea for all three categories of JCE against all accused before the ECCC. ${ }^{179}$

This section revisits of the controversial question on the application of JCE doctrine before the ECCC among international criminal lawyers. Particularly, the question on legality and legitimacy of the application on JCE before the ECCC, where the application of the extended form of JCE (JCE III) would violates the principle of nullum crime sine lege. As below, this chapter intends to discuss such a controversial issue at the ECCC.

\subsection{The Application of JCE before the ECCC}

As mentioned in Chapter 2 regarding the application of JCE in the prosecution (section 2.8), the principle of nullum crimen sine lege applies to various modes of individual criminal responsibility, and then the application of JCE must respect such a principle. Therefore, the first main issue of JCE applicability at the ECCC is that the application should be in accordance with the principle of nullum crime sine lege.

Considering the ECCC Law, the principle of nullum crimen sine lege has also been respected by the ECCC; Article 33 new (2) of the ECCC Law provides that:

"The Extraordinary Chambers of the trial court shall exercise their jurisdiction in accordance with international standards of justice, fairness and due process of law, as set out in Articles 14 and 15 of the 1966 International Covenant on Civil and Political Rights.”

In accordance with this provision, Article 15 of International Covenant on Civil and Political Rights (ICCPR) outlines the principle of legality (nullum crimen sine lege) as a part of ECCC's legal regime.

Article 15 of the ICCPR states that:

\footnotetext{
177 Duch Case, Criminal Case File No 001/18-07-2007-ECCC/OCIJ (PTC 02), ECCC, Decision on Appeal against Closing Order Indicting Kaing Guek Eav alias "DUCH”, 5 December 2008 ['Appeal Decision'], para. 142; After being dismissed by the PTC, the attempt to apply the JCE liability against Duch of the Co-Prosecutors was still remain and on 8 June 2009 the Co-Prosecutors filed the Request for the application of JCE to the Trial Chamber in the Case against Duch, see Case of Duch, Criminal Case File No. 001-18-072007-ECCC-TC, ECCC, Co-Prosecutors' Request for the Application of Joint Criminal Enterprise, 8 June 2009 ['Request for JCE'].

${ }_{178}$ Order on the Application of JCE, supra note 14, paras. 18 - 20.

${ }^{179}$ Ibid., p. 10.
} 
"[N]o one shall be held guilty of any criminal offence on account of any act or omission which did not constitute a criminal offence, under national or international law, at the time when it was committed."

Therefore, the principle of nullum crimen sine lege has been not only been recognized by ICCPR, but has also respected as a fundamental principle of criminal law and a norm of customary international law. This principle requires that a person may only be found guilty of a crime in respect of acts, which constituted a violation of the law at the time of their commission.

Hence, fulfilling this obligation, the crimes that were committed between 1975 and 1979 are encompassed by the ECCC's jurisdiction only if they constituted an international or national criminal offence at that time. The principle of legality also applies to the rule of imputation, for example in the context of JCE, for these rules link the individual conduct to the crimes and as such must be considered as the basis for criminal responsibility. ${ }^{180}$

The question of JCE applicability at the ECCC and the violation of the principle of nullum crimen sine lege have become controversial issues in the proceedings since Ieng Sary brought them to the OCIJ. Ieng Sary claimed many reasons that the JCE is inapplicable before the ECCC and claimed that the application of JCE at the ECCC violates the principle of nullum crimen sine lege. ${ }^{181}$

According to the jurisprudence of the ad hoc tribunals, the mode of liability to be used by the Court must satisfy the four conditions namely: (1) it must be provided for in the Court's basic instruments, explicitly or implicitly; (2) it has had existed under customary international law at the relevant time; (3) the law providing for it must have been sufficiently accessible to the defendants at the relevant time; and (4) the defendants must have been able to foresee that they could be criminally liable for their actions. ${ }^{182}$ If each of four conditions is fulfilled, JCE is a valid mode of liability at the Court.

Regarding this, the highest priority requirement for applying the doctrine of JCE before the Court is that the Court's basic instrument must provide for JCE in its legal regime. The second requirement, which is the question of the existence of the law and the third and the fourth requirements are the question of 'legality' of the application of JCE. ${ }^{183}$

\footnotetext{
${ }^{180}$ Duch Case, Criminal Case File No. 001/18-07-2007-ECCC/OCIJ (PTC 02), ECCC, Amicus Curiae concerning Criminal Case File No 001/18-07-2007-ECCC/OCIJ (PTC 02) submitted by Kai Ambos, 27 October 2008 ['Ambos amicus curiae brief'], p. 20.

${ }^{181}$ JCE Motion, supra note 7. p. 1.

${ }^{182}$ Ojdanić's JCE Decision, supra note 27, para. 49.

${ }^{183}$ In the Duch Case, the Co-Prosecutors state that the application of JEC doctrine at the ECCC should comply with these four requirements: (i)The JCE must be provided for in the ECCC, either explicitly or implicitly; (ii) The JCE must have existed in the law at the relevant time; (iii) The JCE must have been sufficiently accessible to the defendants at the relevant time; and (iv) The JCE must have been sufficiently foreseeable to the defendants at the relevant time, Appeal of Closing Order, supra note 1, para. 49, Ambos amicus curiae brief, supra note 180 , p. 21
} 
According to this, in sum, the condition for applying the doctrine of JCE at the ECCC can be categorised in to two main conditions: (1) ECCC legal regime condition; (2) the legality conditions, which contains two requirements, that is, the existence of the law requirement and the foreseeability and accessibility requirement. As below, each of the conditions will be discussed, respectively.

\subsubsection{The ECCC Legal Regime Condition}

The most important question concerning the application of the JCE doctrine before the ECCC is the question of legality. Hence, whether the ECCC Law provides JCE liability in its legal regime would be the prior condition of that applying. Without this providing, JCE liability will be out of the ECCC's legal regime.

The ECCC Law came into effect in 2004, after the Appeal Decision of Tadic Case had created the doctrine of JCE in 1999. The ECCC Law, Article 29 provides for individual criminal responsibility for any "suspect who planned, instigated, ordered, aided and abetted, or committed" the crimes punishable by the Court. Regarding this, five forms of criminal responsibility are identical to those found in the statutes of the ICTY, ICTR and SCSL and this provision does not explicit include JCE as a form of liability.

However, in accordance with the object and purpose of the ECCC Law, Article 1 of the ECCC Law states that:

"The purpose of the Law is to bring to trial senior leaders of Khmer Rouge and those who were most responsible for the crimes and serious violations...that were committed during the period from 17 April 1975 to 6 January 1979.”

The best way to prosecute the senior leaders and those most responsible successfully, the Court must be able to assign criminal responsibility to the individuals who created and implemented the criminal policies of the Khmer Rouge regime, not just to the individuals who physically perpetrated the crimes that resulted from those policies. As a result, the application of JCE can fulfill that purpose of the ECCC. ${ }^{184}$

Moreover, due to the ad hoc tribunals jurisprudence, each of those tribunals has held that participation in a common criminal plan or purpose is a form of committing a crime. Those tribunals have followed the Tadic Appeal Decision, which held that participation in a JCE is a form of commission and that JCE more accurately reflects the responsibility of co-perpetrators in most international crimes than other modes of liability. ${ }^{185}$

The jurisprudence of international criminal tribunals regarding a JCE as a form of commission is therefore consistent with the purpose of the ECCC

\footnotetext{
${ }^{184}$ See generally ibid., para. 190.

${ }^{185}$ Tadić Appeal Judgment, supra note 3, paras. 188 - 193.
} 
Law, the nature of international crimes and the manner in which other international tribunals have interpreted identical language in their respective statutes. ${ }^{186}$

An individual may be found to have 'committed' a crime through his or her participation in the realisation of a common design and purpose. ${ }^{187}$ The interpretation of 'committed' includes participation in a JCE, and then the ECCC may read 'committed' to include liability for commission through a JCE in accordance with the jurisprudence of the ICTY and the ICTR. ${ }^{188}$ According this, the doctrine of JCE has been already contained in the provision of the ECCC Law, implicitly.

Interestingly, Ambos argues on the individual responsibility in the ECCC Law in his amicus curiae that this provision includes JCE but only applies to JCE I, the basic form. The JCE I resembles co-perpetration in a traditional sense and as such can be considered as commission, but not for JCE III. ${ }^{189}$

Nevertheless, in the Ieng Sary Case, the Co-Investigating Judges held that Article 29 does not expressly refer to JCE, however, JCE is a mode of liability articulated as a form of commission in the Tadic Appeal Judgment at the ICTY, defining three categories of JCE, all of which have the same actus reus element and difference degrees of mens rea element. ${ }^{190}$ Therefore, the Co-Investigating Judges concludes the actus reus and mens rea elements for all three categories of JCE applicable to the international crimes under the jurisdiction of the ECCC. ${ }^{191}$

According to the aforementioned discussion, Article 29 of the ECCC Law, JCE can not only be inferred from the term 'commission' in the provision, but it is also supported by the object and purpose of the ECCC Law, as stated in Article 1. Regarding this, the JCE liability has been included in the ECCC Law and the application of JCE is in the ECCC's legal regime.

\footnotetext{
${ }^{186}$ Appeal of Closing Order, supra note 11, para. 55.

${ }^{187}$ Tadić Appeal Judgment, supra note 3, para. 188.

188 Duch Case, Criminal Case File No. 001/18-07-2007-ECCC/OCIJ (PTC 02), ECCC, Amicus Curiae Brief of Professor Antonio Cassese and Members of the Journal of International criminal Justice on Joint Criminal Enterprise Doctrine, 27 October 2008 ['Cassese amicus curiae brief'], p. 21

${ }^{189}$ Ambos amicus curiae brief, supra note 180, p. 22, Ambos concluded that the CoProsecutors not only ignored this distinction in their discussion of the ECCC Law but consciously leaves open the distinction between JCE I and JCE III when they proposed to charge Duch in the alternative either as a co-perpetrator in the JCE I or for the crimes being a natural and foreseeable consequence of the criminal enterprise (JCE III) Further, the CoProsecutors overlooked the other forms of liability, in particular, the form of imputation for superiors, that is , indirect perpetration based on the theory of control by way of a hierarchical organizational structure”

${ }^{190}$ Order on the Application of JCE, supra note 14, para. 13.

${ }^{191}$ Ibid., para. 23.
} 


\subsubsection{The Condition of Legality}

As above discussed, the application of JCE in the prosecution, in accordance with the ad hoc tribunals jurisprudence, must respect the principle of nullum crimen sine lege. Thus, the application of the doctrine of JCE at the ECCC must fulfill the requirements of nullum crimen sine lege principle. This principle is not only a fundamental principle of criminal law but also a norm of customary international law. It requires that a person may only be found guilty of a crime in respect of acts, which constituted a violation of the law at the time of their commission. ${ }^{192}$

Regarding this, applicability JCE, the doctrine of JCE must be satisfied in accordance with the condition of legality namely: the existence of the law requirement and the foreseeability and accessibility requirement. However, this sub-section only intends to identify each of the requirements under the legality condition, which will be discussed in detail in next section in this chapter (section 4.3)

\subsubsection{The Existence of the Law Requirement}

The existence of the law requirement is the first inquiry for claiming the principle of nullum crimen sine lege. According to this requirement, the existence of the doctrine of JCE at the relevant time must be proven.

Article 2 of the ECCC Law states that:

"Extraordinary Chamber shall be established in the existing court structure, namely the trial court and the supreme court to bring to trial senior leader of Democratic Kampuchea and those who were most responsible for the crimes and serious violations of Cambodian laws related to crimes, international humanitarian law and custom, and international conventions recognised by Cambodia, that were committed during the period from 17 April 1975 to 6 January 1979."

According to this provision, the requirement of the principle of nullun crimen sine lege will be met if JCE liability has been accepted as a mode of participation under either international law or Cambodian law at the relevant time (1975-1979).

Then, to justify this requirement, both international and national law must be taken into account. The regardless of this content in both levels of law, customary international law and Cambodian national Law, the application of JCE would violate the principle of nullum crimen sine lege.

\subsubsection{Foreseeability and Accessiblility Requirement}

The foreseeability and accessibility requirement is an important requirement for testing the legality of the application of JCE at the ECCC. To fulfill this final requirement the question regarding the sufficiently foreseeable and

\footnotetext{
${ }^{192}$ Article II(2) of UDHR and Article 15(1) of ICCPR.

193 Emphasis added by author.
} 
accessible of the doctrine of JCE liability to the defendants during 19751979 must be examined; whether each accused had sufficient notice of this form of liability at the relevant time.

The requirement focuses on the modes of criminal liability in domestic law, that is, the 1956 Cambodian Penal Code and other domestic jurisdiction. The parallel mode of liability refers to the doctrine of acting in pursuance of a common purpose in national law.

\subsection{Analysis of the Legality of the Application of JCE Liability before the ECCC}

As mentioned above, apart from the existence of the ECCC legal regime condition, another condition for applying JCE before the ECCC that must be fulfilled is the condition of legality, which contains two requirements that is the existence of the law requirement and the foreseeability and accessibility requirement. This part intends to discuss the legality of the application of JCE before the ECCC than the fulfilment of both requirements must be concerned.

\subsubsection{The Existence of the Law}

In general, according to Article 2 of the ECCC Law, the requirement of the principle of nullun crimen sine lege will be fulfilled if it is found that JCE have been accepted as a mode of criminal liability under either international law or Cambodian law at the relevant time (1975-1979). However, in the Tadic Case the court should be put more weight on customary international law over domestic law. ${ }^{194}$ As a result, regardless of the content of Cambodian Law, application of JCE liability would not violate the principle of nullum crimen sine lege.

However, in this section, both international law and Cambodian domestic law will be analysed. Thus, according to this enquiry, the doctrine of JCE liability must be existed in international law and Cambodian law at the relevant time

\subsubsection{Customary international law}

According to the Tadić Case, JCE is a relatively new expression, through a similar concept of common criminal purpose or common criminal plan have existed since at least WWII. ${ }^{195}$ This notion is found in three main fundamental documents from the post-War period: the Charter of the

${ }^{194}$ Tadić Appeal Judgment, supra note 3, para 41.
${ }^{195}$ Ibid., para. 190. 
Nuremberg IMT, CCL No. 10 and the Charter of the Tokyo IMT. ${ }^{196}$ According to these provisions, a person who participated in a common plan or conspiracy to commit any crime under these documents would be liable for all acts performed in execution of that common plan or conspiracy. In addition, thousands of post-WWII's trials made JCE a part of customary international law. ${ }^{197}$

At the ECCC in the Ieng Sary Case, the Co-Prosecutors observed that all three categories of JCE have been part of customary international law since well before 1975-1979. This is evident from numerous international statutes, cases and authoritative announcements, as well as domestic cases, supporting the prior existence of JCE. All of this provides cogent evidence of the widespread state practice and opinio juris that establish customary international law. ${ }^{198}$ Furthermore, the inclusion of a 'common plan' as a mode of liability in the Charter of Nuremberg Tribunal, CCL No. 10 and post-WWII war crimes tribunals also crystallized JCE as customary international law. ${ }^{199}$

During the IMT's trials and those conducted under the CCL NO. 10, there were also thousands of national prosecutions. Those prosecutions applied JCE I liability to the cases, which are some of the post-WWII prosecutions that have fulfilled the requirements of the establishment of customary international law: state practice and opinion juris. ${ }^{200}$ The application of JCE II, there is also a series of WWII cases that apply the mode of liability to cases of concentration camps, which demonstrate the existence of JCE II in international criminal proceedings. ${ }^{201}$ Additionally, a few cases have applied

\footnotetext{
196 Article 6 of the Charter of the Nuremberg Tribunal established a broad responsibility based on common plan providing that "[L]eaders, organizers, instigators and accomplices participating in the formula or execution of a common plan or conspiracy to commit any of the foregoing crimes are responsible for all acts performed by any persons in execution of such plan.” Furthermore, Article II (2) of the CCL No 10 provides that a person has "committed" a crime when he...(d) was connected with plans and enterprises involving its commission or (e) was a member of any organization or group connected with the commission of any such crime.”

${ }^{197}$ Appeal of Closing Order, supra note 11, para. 53.

198 Ieng Sary Case, Co-Prosecutors' Supplementary Observations on Joint Criminal Enterprise, Case File No. 002/19-09-2007-ECCC/OCIJ, 31 December 2008, para. 9.

199 Ibid., para. 10.

${ }^{200}$ For instance, the Almelo Trial and the Ponzano case at the British Military Court, the case of Hölzer el al. at Canadian Military Court and the case of Einsatzgruppen at the United States Tribunal, see Appeal of Closing Order, supra note 11, para 53-54; Cassese amicus curiae brief, supra note 188, paras. 33-34; McGill amicus curiae brief, supra note 122, paras. 16-18; Ambos amicus curiae brief, supra note 180, pp. 23-26.

${ }^{201}$ For instance, the case of Dachau Concentration Camp Trial, the case of Hadamar and the case of Mauthausen Camp at the American Military Tribunal and the cases of VelpkeChildrens' Home and the case of Karmer at the British Military Court, see Appeal of Closing Order, supra note 11, paras 53 - 54; Cassese amicus curiae brief, supra note 188, paras. 47 - 48; McGill amicus curiae brief, supra note 122, paras. 20 - 23; Ambos amicus curiae brief, supra note 180, pp. $26-28$.
} 
liability for foreseeable crimes outside the common plan, which constitute to JCE III. ${ }^{202}$

Similarly, the amici curiae briefs of Cassese, McGill and Ambos, point out that the principle of JCE liability was crystallized as customary international law and was recognized before 1975-1979 by the Charter of IMT, CCL No 10. Then, JCE is not a creation of the ICTY in the Tadic Case and the categorization of JCE in the Tadić Case was an attempt to rationalize a vast array of disparate decisions and to set out their rationale. ${ }^{203}$ Moreover, in the Tadic Case, the Appeals Chamber relied on post-WWII case law to establish that "the notion of common design as a form of accomplice liability is firmly established in customary international law”,204

Then, concerning post-WWII case law and opinions of scholars above, it can be generally concluded that the doctrine of JCE liability has been recognised as international customary law in accordance with the two elements: state practice and opinio juris. According this, JCE liability has customary status at the relevant time then it existed in international law during 1970s.

However, to confirm such conclusion, the analysis of customary status of each category of JCE should be taken into account, accurately and separately. In the cases of JCE I and JCE II, they are most clearly supported by the post WWII case law before the military tribunal while the facts of cases referenced in support of JCE III resemble less closely the scenarios with which this latter category is most commonly associated. ${ }^{205}$

To short, regarding the customary law status of JCE I and JCE II, the jurisprudence of international criminal tribunals shows the existence of a rule of international customary law requirements (state practice and opinion juris) of JCE I and JCE II, and therefore this can be considered as international customary law at the relevant time.

On the other hand, JCE III cannot be considered as such. There are only a few cases, which have applied liability for foreseeable crimes outside the

\footnotetext{
202 the post-WWII case of the Essen Lynching Heyer and six others (known as the "Essen Lynching Case or Essen West Case”) Lynching at the British Military Court, the Kurt Goebell et al. (called the "Borkum Island" Case) before a United States military court, Tadić Appeal Judgment, supra note 17, para. 207 - 210, However, in the case of Ieng Sary he argues on the customary status of JCE that JCE liability as created in Tadić case is not customary international law during 1975-1979 because in Tadić case, the Appeals Chamber relied on only a very limited number of cases from a limit number of jurisdictions, see JCE Motion, supra note 7, para. 18

${ }^{203}$ Cassese amicus curiae brief, supra note 188, paras. 33-34; McGill amicus curiae brief, supra note 122, paras. 19.

${ }^{204}$ Tadić Appeal Judgment, supra note 3, para. 220

${ }^{205}$ McGill's amicus curiae brief, supra note 122, para, 24; see also JCE Motion, supra note 8, para. 18; in relation to JCE I, the Appeals Chamber relied on six cases in total, four from British military tribunals, one from Canadian tribunal and one from American tribunal. With respect to JCE II, the Appeals Chamber relied on two cases. For JCE III, a few case and numerous unpublished decisions from post-WWII Italian jurisprudence.
} 
common plan. From the case law referred to by the Tadic Appeals Chamber, only the post-WWII case of Essen Lynching at the British Military Court has done so, but the Appeals Chamber itself concedes that this case could be considered as a case of JCE I. ${ }^{206}$ Therefore, JCE III was not a part of international customary law at the relevant time.

Furthermore, the case law regarding the application of JCE III provides two practical problems; one that the circumstances of this case are not clear on the role or intention of each participant and two, that the court's findings must be inferred from the prosecution's argument and the eventual guilty verdict. Nevertheless, there is some evidence to support the general existence of the JCE III already in the years after WWII. ${ }^{207}$

However, Ambos states in his amicus curiae that JCE III will be recognized as such status only if they are interpreted in the narrow sense as a subcategory of JCE I. ${ }^{208}$

To conclude, in the author's view, only customary status of JCE I and JCE II have been recognised under customary international law at the relevant time, which fulfil the existence of the law requirement in their application. For JCE III, concerning some quality and quantity limits of the cases, its customary status cannot be recognised under customary international law at the relevant time.

\subsubsection{National Cambodian Law}

Article 2 of the ECCC Law mentions the Cambodian laws related to crimes during the Khmer Rouge regime. In this regard, the national Cambodian Law in force during such period was the 1956 Penal Code, published by the Ministry of Justice of the Kingdom of Cambodia. Moreover, no sources reliably and comprehensively update this law through 1975, and no available case law appears to elaborate it. ${ }^{209}$

In this Penal Code, there is no explicit legal basis for JCE, although several articles do address issues related to a common plan by criminalizing actions undertaken by groups of people acting together. Chapter Two of the 1956 Penal Code describes the general characteristics of person punishable for crimes that:

"any person, who willfully participates in the commission of any crimes or offences, either directly or indirectly, shall be punished with the same punishment applicable to the result of instigation, explanation, provision of means or aiding or abetting." 210

In addition, the notion of common plan is suggested in Articles 83 to 87, which establishes indirect participation and complicity as requiring

\footnotetext{
${ }^{206}$ Ambos amicus curiae brief, supra note 180, p. 29.

${ }^{207}$ McGill amicus curiae brief, supra note 122, para, 24.

208 Ambos' amicus curiae brief, supra note 180, pp. 28 - 29.

209 See Report of Group of Expert, supra note 154, para 84.

${ }^{210}$ Unofficial translation in McGill's amicus curiae brief, supra note 122, para 39.
} 
underlying acts that are the result of instigation, explanation, provision of means, or aiding or abetting. ${ }^{211}$

According to this, at the time of the Khmer Rouge regime (1975-1979), which the ECCC has jurisdiction, the Cambodian Penal Law recognize the doctrine of JCE liability.

In addition, the notion of common plan is suggested in Articles 83 to 87 of the 1956 Penal Code, which establishes indirect participation and complicity as requiring underlying acts that are the result of instigation, explanation, provision of means, or aiding or abetting. ${ }^{212}$

According to this, at the time of the Khmer Rouge regime (1975-1979), which the ECCC has jurisdiction, the Cambodian Penal Law recognize the doctrine of JCE liability. Regarding JCE I, it exited unambiguously while JCE III was clearly encompassed by the 1956 Penal Code. Due to JCE II, it can be treated as a sub-category of JCE I if it is interpreted narrowly and can be resembled JCE III if it is interpreted in a broad sense. ${ }^{213}$ As result, it depends if one construes it as a sub-category of JCE I or rather an extension of responsibility within meaning of JCE III. ${ }^{214}$ As to JCE III, there is no provision of the Code that can be read so as to give rise to liability similar to JCE III.

To conclude, the testing of the legality of JCE liability on the first requirement, the existence in the law, of the doctrine in international and domestic law at the relevant time shows that JCE I and JCE II have customary status under international customary international law as well as existed in the 1956 Cambodian Penal Code. As a result, JCE I and JCE II fulfill the requirement to be applied in accordance with the principle of nullum crimen sine lege. On the other hand, JCE III was not a part of international customary law as well as not existed in Cambodian domestic law at the relevant time. Regarding this, JCE III does not fulfill the requirement of the application of JCE. The application on JCE III at the ECCC would be a violation of nullum crimen sine lege.

\subsubsection{Foreseeability and Accessibility}

As mentioned above, the foreseeability and accessibility requirement is an important requirement for testing the legality of the application of JCE at the ECCC. To fulfill this final requirement the question regarding the sufficiently foreseeable and accessible of the doctrine of JCE liability to the defendants during 1975-1979 must be examined; whether each accused had sufficient notice of this form of liability at the relevant time.

\footnotetext{
${ }^{211}$ Ibid., para 39

${ }^{212}$ Ibid.

${ }^{213}$ Ambos' amicus curiae brief, supra note 180, p. 19.

${ }^{214}$ Ibid., p. 30.
} 
The requirement focuses on the modes of criminal liability in domestic law, that is, the 1956 Cambodian Penal Code and other domestic jurisdiction. The parallel mode of liability refers to the doctrine of acting in pursuance of a common purpose in national law.

Considering Cambodian domestic law, there were many criminal codes provided indirect support for JCE as a legal concept by 1975. The 1956 Penal Code used three terms in the article for discussing group liability: coaction; complicity; and co-authorship. ${ }^{215}$

Chapter Two of the Penal Code describes the general characteristics of punishable for crimes. ${ }^{216}$ Article 82 of the Penal Code divides criminal violation involving more than one perpetrator into two categories: co-action and complicities. To qualify as co-actor, an accused must voluntarily and directly participate in the commission of a crime. Conversely, voluntary but indirect participation in the commission of a crime created complicity rather than co-actor. ${ }^{217}$

Article 145 of the Penal Code provided a definition of criminal coauthorship that there exists a 'plurality of authors' when it is established that two or more persons confer or consult with one another regarding the commission of a crime. When the actions of a second person amount only to aiding or assistance, such person is considered an accomplice rather than a co-author. ${ }^{218}$

Article 82 also provides a more detailed definition of complicity liability for helping to clarify the differences between the three concepts. Moreover, the concepts of provocation $^{219}$; instruction ${ }^{220}$; provision of means ${ }^{221}$; and aiding or assisting ${ }^{222}$ the principle to commit the substantive crime are also provided in the Penal Code.

\footnotetext{
${ }^{215}$ Watkins \& DeFalco, supra note 12, p.70.

${ }^{216}$ Ibid., Article 76 of the Penal Code states that any competent person is liable for his or her criminal actions unless there exists: (1) an exception in the law; (2) a legal justification; (3) a legal excuse; or (4) the statute of limitation has expired.

${ }^{217}$ Ibid., pp. $74-75$.

${ }^{218}$ Ibid., p. 75.

${ }^{219}$ Ibid., Article 84 provides that "Provocation" consists of suggestions, orders, or advice from a person who either is in a position of authority over the principal author or induces him to act by use of gifts, promises or threats. These acts should also be specifically designed to induce the principal author to act criminally.

${ }^{220}$ Ibid., p. 76, Article 85 provides that "Instruction" consists of the accused providing information to the principal perpetrator "with a view to bring about the commission of the substantive crime. It is unclear whether this view or intent is specific to the charged crime $r$ whether it is a more general desire to bring about criminal action.

${ }^{221}$ Ibid., Article 86 creates complicity liability for anyone who provides the principal with the means to commit the substantive crime. The Article requires that the mens provided by material to the ultimate commission of the crime and be provided by the accused with the ultimate commission of the crime in mind.

${ }^{222}$ Ibid., Article 87 provides that "criminal aid and assistance" can create either co-action and complicity. Criminal aid or assistance takes place when an accused helps to prepare or generally facilitate criminal action. This aid or assistance evolves from complicity to co-
} 
In this regard, the provisions of the Penal Code generally supports the basic concept of JCE liability, however, there are no case law interpreting its provisions. ${ }^{223}$ Moreover, the post-WWII jurisprudence served the accused persons with some general notice that collective criminality triggers individual responsibility. There are many sources of international law that generally provide for JCE.

Thus, the foreseeability and accessibility requirement is fulfilled that it is sufficient foreseeable and accessible of the doctrine of JCE to the defendants during 1975-1979 and the accused had sufficient notice of this form of liability at the relevant time.

The foreseeability and accessibility requirement is an important requirement for testing the legality of the application of JCE at the ECCC. To fulfill this final requirement the question regarding the sufficiently foreseeable and accessible of the doctrine of JCE to the defendants during 1975-1979 must be examined; whether each accused had sufficient notice of this form of liability at the relevant time.

As abovementioned, JCE I and JCE II existed in customary international law at the relevant time. Furthermore, they exist not only in customary international law, but also in Cambodian Penal Law. Hence, both JCE I and JCE II were accessible and foreseeable to the defendants during 1975$1979 .^{224}$

However, this is not in the case with regard to JCE III because it was not a part of international customary law as well as Cambodian domestic law, and then the JCE III liability was inaccessible and unforeseeable to the accused during the relevant time.

At the ECCC in the Ieng Sary Case, the Investigating Judges had the Order states that all three categories of JCE liability applicable at the ECCC and the application of those three types of such doctrine not violate the principle of legality (nullum crimen sine lege). It can be noted from the foregoing that only JCE I and II that applicable in accordance with the principle of nullum crimen sine lege, but the application of JCE III before the ECCC would violate the principle of nullum crimen sine lege.

All in all, only JCE I and JCE II fulfill the requirements of the principle of legality: the existence in the law; and accessibility and foreseeability. Then the application of JCE I and JCE II liability for the crimes committed during the Khmer Rouge regime before the ECCC would not violate of the nullum crimen sine lege principle. Nevertheless, the application of JCE III before the ECCC would violate the principle of legality.

action when the principal author makes use of such aid or assistance in committing the substantive crime.

${ }^{223}$ Ibid.

${ }^{224}$ Ambos' amicus curiae brief, supra note 180, p. 30. 


\subsection{Recent Jurisprudence of the ECCC on the Legality of the Application of JCE}

As mentioned earlier, the issue of the use of JCE is ambiguous at the ECCC. The attempt of the Co-Prosecutors to apply JCE against Duch and other accused, created the jurisprudence dealing with JCE at this Court. This section aims to explore the jurisprudence of the ECCC regarding the JCE as such, which touches upon the question on the legality of the application of this doctrine before the ECCC.

According to the facts, on the 9 December 2009, in the Ieng Sary Case, the Co-Investigating Judges issued the Order states that the actus reus and mens rea elements of all three forms are applicable at the ECCC and the application of JCE is not a violation of the principle of nullum crimen sine lege. ${ }^{225}$ Subsequently, the Civil Party and the three accused, Ieng Thirith, Ieng Sary and Kheiu Samphan, appealed against such Order. ${ }^{226}$

Ultimately, recently, on 20 May 2010, the PTC made the Decision on the Appeals Against the Co-Investigating Judges' Order on JCE. ${ }^{227}$ According to the Decision, the PTC states that JCE I and JCE II applicable at the ECCC:

" $[\mathrm{J}] \mathrm{CE}$ I and II are the forms of responsibility the were recognized in international criminal law since the post-WWII international instruments and international military case law [...] as well as its earlier finding that these forms of liability have an underpinning in the Cambodian law concept of co-authorship applicable at the time, the PTC has no doubt that liability based on a common purpose, design or plan was sufficiently accessible and foreseeable to the defendants.” 228

Due to this pronouncement, both doctrines of JCE I and JCE II existed in international customary law as well as national law at the relevant time. As a result, JCE I and JCE II applicable at the ECCC and the application of such two forms of JCE does not breach the principle of nullum crimen sine lege.

\footnotetext{
225 See Order on JCE, supra note 14.

${ }^{226}$ See Ieng Sary Case, Criminal Case File No. 002/19-09-2007-ECCC-OCIJ (PTC 37), ECCC, Appeal Brief against the Order on the Application at the ECCC of the Form of Liability known as Joint Criminal Responsibility, 8 January 2010; Ieng Sary Case, Criminal Case File No. 002/19-09-2007-ECCC-OCIJ (PTC 38), ECCC, Ieng Thirith defence Appeal Against 'Order on the Application at the ECCC of the Form of Liability Known as Joint Criminal Enterprise’ of 8 December 2009, 18 January 2010; Ieng Sary Case, Criminal Case File No. 002/19-09-2001-ECCC (PTC 35), ECCC, Ieng Sary Appeal Against the OCIJ's Order on the Application at the ECCC of the Form of Liability Known as Joint Criminal Enterprise, 22 January 2010; Ieng Sary Case, Criminal Case File No. 002/19-09-2001-ECCC (PTC 39), Appeal Against the Order on the Application at the ECCC of the Form of Liability Known as Joint Criminal Enterprise, 3 February 2010.

227 See Ieng Sary Case, Criminal Case File No. 002/19-09-2007-ECCC-OCIJ (PTC 38), ECCC, Decision on the Appeals Against the Co-Investigating Judges Order on Joint Criminal Enterprise (JCE), 20 May 2010 ['JCE Decision'].

${ }^{228}$ Ibid., para 72.
} 
On the other hand, in the case of JCE III, the PTC reviews the post-WWII trials and reaches a different conclusion as the ICTY jurisprudence that:

“[J]CE III purports to attach liability for crimes falling outside the common criminal purpose but which were natural consequences of the realization of the purpose and foreseeable for to accused. The PTC has not been able to identify in the Cambodian law, applicable at the relevant time, any provision that could has given notice to the Charged Persons that such extended form of responsibility was punishable as well. In such circumstances, the principle of legality requires the ECCC to refrain form relying on the extended form of JCE in its proceedings”229

According to this, the ECCC rejects the doctrine of JCE III by concluding that JCE III doctrine does not fulfil the existence of the law requirement as well as the foreseeability and accessibility requirement. Therefore, the application of JCE III would violate the principle of nullum crimen sine lege.

As abovementioned, the recent decision of the ECCC regarding JCE makes the clear answer of the question on the legality of JCE applicability before the ECCC that only the use of JCE I and JCE II is accepted and the application of such two form does not violate the principle of legality. Conversely, the application of JCE III before the ECCC is rejected and the use of this form would violate the principle of nullum crimen sine lege.

\subsection{Legitimacy of the Application of JCE Liability}

The purposes of the prosecution of violations of international criminal law are practical promotes, the discovery of the truth, the creation of an accurate historical record, vindication of the rights of victims, the advancement of justice and education of the public by more accurate reflecting the criminality of the accused. ${ }^{230}$ Moreover, there are many factors that constitute such purposes, including the spread of human rights doctrines and the increasing feeling that the most effective means of enforcing respect for such rights. ${ }^{231}$ These factors must be concerned by all international criminal tribunals dealing with crimes of mass atrocity, including the ECCC.

As above discussed above in section 2.8, legitimacy is the condition for achieving both international criminal law and human rights law objectives. Then for such goals, the legitimacy of international criminal proceedings need to balance between goals of human rights law, protecting fundamental rights of the accused in any state of the prosecution, and goals of

\footnotetext{
${ }^{229}$ Ibid., para 87.

230 See M.C. Bassiouni, 'Searching for Peace and Achieving Justice: The Need for Accountability', 59 Law and Contemporary Problems (1996) p. 24.

${ }^{231}$ Cassese, supra note 105, p. 123, other factors such as the failure of national courts to bring to trial the alleged authors of egregious breaches amounting to international crimes and the objective merits of international judicial mechanisms.
} 
international criminal law, to bring the perpetrator to justice, on a case-bycase basis.

Due to the ECCC, the Court was established to bring to trial the former senior leaders of the Khmer Rouge in accordance with the goals of international criminal law. However, the proceedings at the ECCC must concern about goals of human rights law, to protect the rights of the accused. The application of JCE liability category three before the ECCC violates fundamental right of the accused, under the principle of nullum crimen sine lege, which contradict the human rights law's goals. Thus, to consider the appropriate balance between the international criminal law and human rights law elements of their jurisprudence.

\subsubsection{Legitimacy and Values Balancing in International Criminal Proceedings}

Law and legitimacy have a long and close relationship. In simple term, the legitimacy is defined as the quality of being legal or acceptable, whereas legality is the fact that something is allowed by the law. ${ }^{232}$ However, legitimacy is a wider concept than the concept of lawfulness because it includes legality, i.e., lawfulness of norms, institutions, situations (orders) or behaviour of various actors. ${ }^{233}$

Lawfulness is one, in 'normal' cases the most important, element or aspect, of legitimacy. However, legitimacy is more than simply lawfulness because it also includes morality or a sense of fairness or justice. ${ }^{234}$ Moreover, in the application of the concept of legitimacy in courts and tribunals, legitimacy addresses the aspect in light of moral or political values. ${ }^{235}$

Hence, the question on legitimacy of the application of JCE liability before the ECCC must concern not only legal values of the proceedings but also has moral and political values of such application.

\footnotetext{
${ }^{232}$ Cambridge Advance Learner' Dictionary, $3^{\text {rd }}$ eds $<$ http://dictionary.cambridge.org $>$ accessed on 1 May 2010.

233 R. Müllerson, 'Aspects of Legitimacy of Decisions of International Courts and Tribunals: Comments', in R. Wolfrum and V. Röben (eds.), Legitimacy in International Law (Springer, Berlin 2008) p. 191.

${ }^{234}$ Ibid.

235 See T. Treves, 'Aspects of Legitimacy of Decisions of International Courts and Tribunals', in R. Wolfrum and V. Röben (eds.), Legitimacy in International Law (Springer, Berlin, 2008) pp. 169 - 188.
} 


\subsubsection{Legal Values}

\section{(i) Influence of Human Rights Law}

The human rights paradigm appears to have been one of the factors in legal value of the legitimacy of international criminal proceedings. The ECCC Law incorporates Article 15(1) of the ICCPR that provides that no one shall be held guilty of any act that did not constitute a criminal offence, under national or international law, at the time when it was committed. Article 15(2) ensures that Article 15 (1) is not interpreted as a barrier to international criminal liability. ${ }^{236}$ As a result, the principle of nullum crimen sine lege, which is not only a fundament principle of human rights law but also essentially a principle of justice, must be respected in international criminal justice. ${ }^{237}$ Moreover, in considering the principle of nullum crime sine lege, the ECCC must be satisfied that the applicable criminal liability was sufficiently foreseeable and accessible at the relevant time.

Such criteria has been discussed above that only the application of JCE I and JCE II that fulfill the satisfaction in accordance with the principle of nullum crimen sine lege. On the other hand, the application of JCE III before the ECCC cannot be satisfied that legal value. Then, the application of JCE III before the ECCC would lack of legal value, which constitutes legitimacy of the proceedings.

\section{(ii) Prosecutorial tools}

The principle of nullum crimen sine lege represents fundamental principles of criminal justice then this principle applied not only to the substance of specific international crimes but also to various modes of individual criminal responsibility, which are the tools in the prosecution before international criminal tribunals.

The ECCC Law Article 29 provides for prosecutorial tools to bring the accused to trial in five forms of individual criminal responsibility: planning; instigating; ordering; aiding and abetting; and committing the crimes punishable by the Court. In addition, in accordance with the jurisprudence of ad hoc tribunals, the doctrine of JCE is also included as a tool in the prosecution under the scope of 'committing'.

Article 1 of the ECCC Law states the purpose of the Law that bringing to trial senior leaders of Democratic Kampuchea and those who were most responsible for the crime under the regime. Then, this supports the application of JCE before the ECCC in two ways. First, the Chambers is

\footnotetext{
${ }^{236}$ Article 15(2) of the ECCC Law provides that:

"[n]othing in this article shall prejudice the trial and punishment of any person for any act or omission which, at the time it was committed, was criminal according to the general principle of law recognized by the community of nations."

${ }^{237}$ Ojdanić's JCE Decision, supra note 27, para. 37.
} 
created to prosecute the senior leaders and those most responsible. The crimes committed the regime from 1975 to 1979 were generally not the isolated acts of individuals, but the result of deliberate criminal policies designed and enforced by the Khmer Rouge. ${ }^{238}$ Therefore, to successfully realize its mandate to prosecute the senior leaders and those most responsible for those crimes, it is critical that the ECCC is able to assign criminal responsibility to the individuals who created and oversaw the implementation of the Khmer Rouge's criminal policies, as opposed to the individuals who simply physically perpetrated the crimes carried out pursuant to those policies ${ }^{239}$

Secondly, it is the nature of core international crimes to be mass-scale crimes committed by a plurality of perpetrators and frequently evidence of participation by an accused in scare then the JCE doctrine has the potential to stretch criminal liability to a point where the legitimacy of international criminal law will be threatened. ${ }^{240}$ Regarding this, the interpretation of Article 29 as including JCE is essential to effectively prosecuting the large-scale international crimes falling within the jurisdiction of the ECCC. Therefore, although only some members of the group may physically perpetrate the criminal act, the participation and contribution of other is often vital in facilitation the commission of the offence. It is to say, moral gravity of such participation is no different from that of those actually perpetrating the acts in question. ${ }^{241}$

Thus, in sum, to consider the legal value of the application of JCE liability, it seems to be that JCE liability would be one of the suitable tools for prosecuting crimes committed under the regime before the ECCC.

\subsubsection{Moral Values}

The influence of moral values in the legitimacy of criminal justice is based on the internalization of feelings of responsibility to follow principles of personal morality. ${ }^{242} \mathrm{~A}$ core element of moral values is that people feel a personal responsibility to follow those values, and feel guilty when they fail to do so.

Furthermore, the moral values include morality or a sense of fairness or justice. Although ideally these inquiries have to coincide, if not completely, then at least quite substantially, in practice they may clash, and in such a case we may indeed be able to say that something is illegal but legitimate or, vice versa, legal but illegitimate. ${ }^{243}$

\footnotetext{
${ }^{238}$ Report of the Group of Experts, supra note 154, paras. 6, 15.

${ }^{239}$ Ieng Sary Case, Criminal Case File No. 002/19-09-2007-ECCC/OCIJ, ECCC, CoProsecutors' Respond to Ieng Sary's Motion on Joint Criminal Enterprise, 11 August 2008, para. 13.

240 Danner and Martinez, supra note 103, p. 132.

${ }^{241}$ Ibid., para. 14.

${ }^{242}$ T.R. Tyler, 'Legitimacy and Criminal Justice: The Benefits of Self-Regulation', 7 Ohio State Journal of Criminal Law (2009) p. 329.

${ }^{243}$ Müllerson, supra note 233, p. 191.
} 
A crisis moral value of legitimacy arises in perceptions of distributive justice, or the proportionality and consistency of legal responses to condemnable behaviors. ${ }^{244}$ For the law to be perceived as morally credible, it should punish those who deserve it, protect those who do not, and allocate punishments in proportion to the perceived harm. ${ }^{245}$

The establishment of the ECCC is the product of the attempt, more than twenty years. This hybrid Court has specific purpose for bringing to justice of the senior leaders and those most responsible for crimes committed under the Khmer Rouge regime as stated as its purpose in the ECCC Law. Then, to consider the moral value of the legitimacy of the proceedings before this Court should concern about the prosecution of the condemnable acts of the accused. The testing of legal value of the ECCC proceedings, as discussed above, would be a conflict to legal value, the violation of the principle of nullum crimen sine lege of JCE III applicability. However, to balance these values, all the facts and legal issues should be taken into account.

Thus, the clash between the purpose of the ECCC and the sense of fairness or justice regarding the application of JCE III before the ECCC violates the principle of nullum crimen sine lege should be balanced on a case-by-case basis.

\subsubsection{Political Values}

As a norm, the political constraints are voluntarily entered into within international society, and that have a basis recognizably different from legal and moral prescriptions, however much the political play may be rhetorically coloured by legal or moral language". ${ }^{246}$

In general, in post-conflict societies, it is often very difficult to re-establish the rule of law, and particularly hard to commence national proceedings for past war crimes and human rights abuses. One of the most important reasons is the lack of political will. ${ }^{247}$ As a result, political will contributes to the legitimacy of the court and following judicial announcements of such court. Regarding the ECCC, its establishment was strongly supported by the Cambodian government. Then, the political will of Cambodia touch on the legitimacy of the ECCC and its proceedings. ${ }^{248}$

\footnotetext{
244 J. Fagan, 'Legitimacy and Criminal Justice: Introduction', 6 Ohio State Journal of Criminal Law (2008) pp. 129 - 130.

245 Ibid.

${ }^{246}$ Müllerson, supra note 233, p. 192.

${ }^{247}$ I. Šimonović, 'Dealing with the Legacy of Past War Crimes and Human Rights Abuses', 2 Journal of International Criminal Justice (2004) p. 206.

${ }^{248}$ As a hybrid Court, however, the ECCC has hybrid characteristics, which involving the national and international judges and prosecutors. Regarding this, the local judges may make the work of the court faster, but it also brings into the proceedings values, including the political value. ${ }^{248}$ As a result, it might be decisive on which judges represent the majority, local or international ones, see ibid., pp. 708 - 709.
} 
To sum up, the JCE liability has been developed largely as a way to satisfy powerful moral and political interests in holding venal leaders responsible for their misdeeds, which are often obscured by the scale and complexity of abuses. However, in consider of legitimacy of such application, should concern all aspects of legal, moral and political values in the international criminal proceedings.

\subsubsection{Critique on Legitimacy: Case of Duch}

Based on a case-by-case basis, legitimacy of the application of JCE liability before the ECCC has to be examined in accordance with the facts in each case. In this section, the author will criticize the legitimacy of the application of JCE against Duch the first accused of the ECCC.

\subsubsection{Facts of the case}

Duch has been charged and sent to trial for crimes against humanity, grave breaches of the Geneva Conventions of 1949, and homicide and torture pursuant to the 1956 Cambodian Penal Code. He held a position as a commander of a unique in the network of security centres given its direct link to the Central Committee and its role in the detention and execution called S-21, also known as Toul Sleng torture house, from 1975 to 1979. At S-21, over 15,000 prisoners were executed or died from torture and/or poor detention conditions at S-21 during the regime. ${ }^{249}$

In the Case of Duch, the Co-Prosecutors appealed on the basis that Duch should be charged via JCE because of his conduct as a commander of the detention, interrogation and execution camp known as S-21 during the Khmer Rouge regime. In addition, the facts in the Indictment show that he participated at every state of S-21's operations. ${ }^{250}$

According to his status, the three forms of liability characterized as ordering, instigating and planning are not broad enough to cover the full criminality of Duch's actions. Furthermore, the two other forms of liability, aiding and abetting and superior order responsibility, do not fully reflect the particular criminal role that Duch had at S-21. ${ }^{251}$ Therefore, the indictment is unduly narrow without JCE and there is a significant possibility that Duch would not be fully held accountable for his actions. ${ }^{252}$

The jurisprudence of international criminal tribunals demonstrates that an accused's acts may be sufficient to attract liability as a co-perpetrator in a JCE even where such acts may not be sufficient for other forms of liability.

\footnotetext{
${ }^{249}$ Case Information Sheet of Kiang Guek Eav alias Duch, $<$ http://www.eccc.gov.kh/english/cabinet/files/Case_Info_DUCH_EN.pdf > accessed on 1 May 2010.

250 Request for JCE, supra note 177, para. 30.

251 Appeal on Closing Order, supra note 11, paras. $64-69$.

${ }^{252}$ Ibid., para. 43.
} 
For example, in the context of prison camp, it has been held that merely "holding an executive, administrative, or protective role in a camp constitutes general participation in the crimes committed therein." 253

Then, the Co-Prosecutors requested for the application of JCE I, Duch's intended his actions to contribute to S-21's criminal purpose; JCE II, Duch's knowledge of the system of ill-treatment within S-21 is clear from the facts; and JCE III, the crimes identified in the Indictment were the nature and foreseeable consequences of the execution of the purpose of JCE. ${ }^{254}$

\subsubsection{Analysis of the Legitimacy}

To analyse legitimacy of the application of JCE in the Case of Duch before the ECCC, the legal value, moral value as well as political value in the proceedings has taken into account.

As legal value, the proceeding of the ECCC, in every state, has to respect the fundamental principle of human rights law, in particular, the principle of nullum crimen sine lege. As a result, the application of modes of individual criminal liability, including JCE, has to be applied in accordance with such principle.

The five prosecutorial tools in the ECCC Law do not fully reflect the particular criminal role that Duch had at S-21. ${ }^{255}$ As a result, the JCE is an appropriate tool for prosecuting the accused in the ambit of the commission under Article 29 of the ECCC Law in accordance with the jurisprudence of the ad hoc tribunals. However, it is clear that the application of JCE III violates the principle of nullum crimen sine lege because it did not exist in international customary law and national Cambodian law at the relevant time. Moreover, it was not accessible and foreseeable to the defendants during 1975-1979.

Regarding the political value, the prosecution at the ECCC has been strongly supported by the Cambodian government. Then, the political will of the mechanism of the ECCC contributes to the legitimacy of the proceedings of the ECCC.

Moral value of the prosecution, as discussed above regarding the purposes of the forming of the ECCC is for bringing to justice the senior leaders and those most responsible for the crimes committed under the regime. Therefore, the moral value of this proceeding is based on personal morality that the perpetrators must be prosecuted and punished for the crimes committed.

Therefore, the question of legitimacy of the application of JCE liability in the Duch Case is the balancing between two conflicting values: legal and

\footnotetext{
${ }^{253}$ Ibid., para. 47.

${ }^{254}$ Request for JCE, supra note 177, para. 30

${ }^{255}$ Appeal on Closing Order, supra note 11, paras $64-69$.
} 
moral. In the other words, it is the work of compromising the application of JCE III, which violates the principle of nullum crimen sine lege, against Duch through the purpose of the establishment and proceeding of the ECCC.

To conclude, in the author's view, with regard to the purpose of the prosecution at the ECCC, the JCE liability is an important prosecutorial tool for bringing Duch to justice. Even the application of JCE III would touch the issue of illegality; however, the application of all three categories of JCE liability before the ECCC against Duch, who committed serious international crimes during the Khmer Rouge regime, is still legitimate. In the instance case, JCE would be as an appropriate tool to bring to trial of the accused, then the author would rather weight the goal of ECCC in international criminal law paradigm, which is the moral value of the proceedings, over the goal of human rights law. Accordingly, it seems that although the application of JCE III before the ECCC may seems to be illegal, it can be argued that the application of JCE liability before the ECCC is still legitimate. Hence, according to the author's view, the doctrine of JCE liability may be a legitimate tool in the prosecution of Duch at the ECCC. 


\section{Conclusion}

Although the jurisprudence of the international criminal tribunals shows that the doctrine of JCE is one of the most important tools in the prosecution. The judicial innovation of JCE is not a kind of crime but a kind of criminal responsibility, which has grown to play a major role in the charges and convictions before international criminal tribunals. However, this doctrine is also one of the most difficult legal doctrines to have emerged from the ICTY over the past fifteen years. The more recent jurisprudence of the ICTY, ICTR, SCSL and ECCC evidences some problematic issues regarding the application of JCE liability in the prosecution.

The doctrine of JCE is a one of the most extensively used tool in the prosecution in international criminal justice. However, it is also one of the most controversial modes of individual criminal responsibility in international law. The doctrine is considered as one of the most effective tools, which can be employed to convict individuals of core international crimes, where there is no direct evidence of the actual participation of the accused in such crime.

This doctrine has been frequently used by international criminal tribunals, including the ECCC. In the same way, the use of JCE before the ECCC has become a problematic issue, especially, the question on the legality and legitimacy of JCE applicability before the ECCC. The employment by the Co-Prosecutors face the important question that whether the application of JCE before the ECCC, for taking into account the crimes committed during 1975 to 1979, violates the principle of nullum crimen sine lege.

As a general matter, the ECCC was created by the negotiation between the Cambodian government and the UN for bringing to trial senior leaders and those most responsible for crimes committed under the Khmer Rouge regime, which is the main purpose of the Court stated in the ECCC Law. Moreover, as an international criminal tribunal, every state of the proceeding in the ECCC must respect human rights standards. As a result, the fundamental principle of legality (nullum crimen sine lege), which requires that a person may only found guilty in respect of acts that constituted a violation of the law at the time of their commission, must be respected. This principle of nullum crimen sine lege has been recognised by international law instruments, i.e., UDHR, ICCPR and Statutes of international criminal tribunal such as ICTY, ICTR, SCSL, ICC, and ECCC. As a result, this principle will be applied not only for specific international crimes, but also equally to the various mode of individual criminal responsibility under the ECCC Law.

Secondly, according to the jurisprudence of the ad hoc tribunals, JCE is considered as a mode of individual criminal responsibility in the ambit of 'commission' pursuant to Article 29 of the ECCC Law. JCE as a form of 
commission is consistent with the purpose of the ECCC Law, the nature of international crimes and the manner in which other international tribunals have interpreted identical language in their respective statutes.

Thirdly, in the author's view, however, the application of JCE before the ECCC breached the principle of nullum crimen sine lege, particularly JCE III. It seems unfair to the individual to understand the complexities of JCE III and to appreciate that he may liable for core international crimes in accordance with the doctrine. Importantly, JCE III did not have customary status, which has been recognised as customary international law at the relevant time and there was no sufficient foreseeable and accessible of the doctrine of JCE liability, in particular JCE III, to the defendants during 1975-1979 and the accused had no sufficient notice of this form of liability at the relevant time.

Fourthly, in addition, JCE III did not exist in the 1956 Cambodian Penal Code, and then the JCE III was inaccessible and unforeseeable to the accused during the relevant time.

Fifthly, JCE I and JCE II fulfil the requirements of the principle of legality: the existence of the law; and accessibility and foreseeability. Then the application of JCE I and JCE II liability for the crimes committed during the Khmer Rouge regime before the ECCC would not violate of the nullum crimen sine lege principle.

Sixthly, although the application of JCE is illegal because it would violate the principle of nullum crimen sine lege, in particular JCE III, legitimacy of the application JCE must consider not only the legal value, but also political and moral values of the case. Hence, in this regard, all of three valued will be balanced and the balancing act would be based on a case-by-case basis.

Seventhly, in the Case of Duch, the legitimacy of the application of JCE before the ECCC has to balance between legal and moral values of the case. The legal value in this case, which contradicts the goal of human rights to protect the accused's rights because the application of JCE III breaches of the nullum crimen sine lege. The moral value in this case, which is the goal of international criminal law to bring senior leaders to justice, on the other hand. In the author's view, considering the purpose of the prosecution at the ECCC, the JCE liability is an important prosecutorial tool for bringing Duch to justice. Although the application of JCE III may touch on the issue of illegality; however, the application of all three categories of JCE before the ECCC against Duch is still legitimate.

Finally, as reasons noted above, in the Duch Case, the JCE would be a legitimate mode of individual criminal responsibility. According to this concern, the JCE is a legitimate prosecutorial tool in the Duch Case before the ECCC. However, for other cases before the ECCC, legitimacy of the application of JCE against them, should be considered separately on the ground of a case-by-case basis. 
To conclude, in the author's view, the JCE is a legitimate and satisfactory tool in the prosecution. The doctrine of JCE continues to be used widely in the prosecution for core international crimes before international criminal tribunals, in particular the ECCC. It seems that the Co-Prosecutors intend to employ JCE as a prosecutorial tool against all the accused, not only Duch, but also Ieng Sary, Ieng Thirith, Nuon Chea and Kheiu Samphan. Then, the serious concern in the case of the ECCC is not only the legality of JCE applicability before the Court, but also the legitimacy of the application as such. Ultimately, the employment of JCE before the ECCC will mirror the credibility and authority of the ECCC in the near future. 


\section{Bibliography}

\section{Books}

Bassiouni, Cherif M., Introduction to International Criminal Law (Transnational Publishers, New York, 2003)

Boas, Gideon, Bischoff, James L. and Reid, Natalie L., International Criminal Law Practitioner Library Volume I: Forms of Responsibility in International Criminal Law (Cambridge University Press, New York, 2007)

Cassese, Antonio (ed.), The Oxford Companion to International Criminal Justice (Oxford University Press, New York, 2009)

Cryer, Robert et al., An Introduction to International Criminal Law and Procedure, (Cambridge University Press, Cambridge, 2008)

De Than, Claire and Shorts, Edwin, International Criminal Law and Human Rights (Sweet \& Maxwell, London, 2003)

Damgaard, Ciare, Individual Criminal Responsibility for Core International Crimes, (Springer, Berlin, 2008)

Ratner, Steven R., Abrams, Jason S. and Bischoff, James L., Accountability for Human Rights Atrocities in International Law: Beyond the Nuremberg Legacy, $3^{\text {rd }}$ eds. (Oxford University Press, New York, 2009)

Schabas, William A., The International Criminal Court: A Commentary on the Rome Statute (Oxford University Press, New York 2010) pp. $430-437$.

Triffterer, Otto, Commentary on the Rome Statute of the International Criminal Court: Observers' Notes, Article by Article, $2^{\text {nd }}$ edn. (Hart, Oxford 2008) pp. $760-763$.

\section{Articles}

Ambos, Kai, 'Joint Criminal Enterprise and Command Responsibility', 5 Journal of International Criminal Justice (2007) pp. 159 - 183.

Bardar, Mohamed Elewa, “ “Just Convict Everyone!” - Joint Perpetration: From Tadić to Stakić and Back Again', 6 International Criminal Law Review (2006) pp. 293 - 302.

Boas, Gideon, 'The Difficulty with Individual Criminal Responsibility in International Criminal Law' in Stahn, Carsten and van den Herik, Laissa (eds.), Future Perspectives on International Criminal Justice (T·M·C Asser Press, The Hague, The Netherlands, 2010) p. $501-519$.

Buckley, Aron J., 'The Conflict in Cambodia and Post-Conflict Justice' in Bassiouni, M. Cherif (ed.) Post-Conflict Justice (Transitional Publishers, New York, 2002) pp. 635 - 657.

Cassese, Antonio, 'The Rationale for International Criminal Justice', in A. Cassese (ed.), The Oxford Companion to International Criminal Justice (Oxford University Press, New York, 2009) pp. 123 - 130. 
D'Amato, Anthony, 'On the Legitimacy of International Institutions', in Wolfrum, Rüdiger and Röben, Volker (eds.), Legitimacy in International Law (Springer, Berlin, 2008) pp. 83 - 92.

Danner, Allison Marston and Martinez, Jennifer S. 'Guilty Associations: Joint Criminal Enterprise, Command Responsibility, and the Development of International Criminal Law', California Law Review 93 (2005) pp. 75 - 169.

De Nike, Howard J., 'Reflections of a Legal Anthropologist on the Trial of Pol Pot and Ieng Sary' in de Nike, Howard J., Quigley, John and Robinson, Kenneth J. (eds.), Genocide in Cambodia: Documents from the Trial of Pol Pot and Ieng Sary (University of Pennsylvania Press, Philadelphia, 2000)

Easterday, Jennifer, 'Obscuring Joint Criminal Enterprise Liability: The Conviction of Augustine Gbao by the Special Court of Sierra Leone', 3 Berkley Journal of International Law Publicist (2009) pp. $36-46$.

Eser, Albin, 'Individual Criminal Responsibility', in Cassese, Antonio, Gaeta, Paola and Jones, John R.W (eds.), The Rome Statute of the International Criminal Court: A Commentary Volume I (Oxford University Press, New York 2002) pp. 802 - 803.

Fagan, Jeffray, 'Legitimacy and Criminal Justice: Introduction', 6 Ohio State Journal of Criminal Law (2008) pp. 123-140.

Lamb, Susan, 'Nullum Crimen, Nulla Poena Sine Lege in International Criminal Law', in Cassese, Antonio, Gaeta, Paola \& Jones, John R.W.D (eds.), The Rome Statute of International Criminal Court: A Commentary (Oxford University Press, New York, 2002) pp. 733 766.

Müllerson, Rein, 'Aspects of Legitimacy of Decisions of International Courts and Tribunals: Comments', in Wolfrum, Rüdiger and Röben, Volker (eds.), Legitimacy in International Law (Springer, Berlin 2008) pp. 189 - 201.

Nouwen, Sarah M.H., 'Hybrid Courts': The Hybrid Category of a New Type of International Crimes Courts', 2 Utrecht Law Review (2006) pp. $190-214$.

Osiel, Mark J., 'Modes of Participation in Mass Atrocities', 38 Cornell International Law Journal (2005) pp. 793 - 822.

Ratner, Steven R., Accountability for the Khmer Rouge: A (Lack of) Progress Report, in Bassiouni, M. Cherif, Post-Conflict Justice (Transitional Publishers, New York, 2002) pp. 613 - 621.

Robinson, Darryl, 'The Identity Crisis of International Criminal Law', 21 Leiden Journal of International Law (2008) pp. 925 - 963.

Schabas, William A, 'Mens Rea and the International Criminal Tribunal for the Former Yugoslavia', 37 New England Law Review (2003) pp. $1015-1036$.

Šimonović, Ivan, 'Dealing with the Legacy of Past War Crimes and Human Rights Abuses', 2 Journal of International Criminal Justice (2004) pp. $701-710$. 
Swart, Bert, 'Modes of International Criminal Liability' in Cassese, Antonio (ed.), The Oxford Companion to International Criminal Justice (Oxford University Press, New York, 2009) pp. 82 - 93.

Treves, Tullio, 'Aspects of Legitimacy of Decisions of International Courts and Tribunals', in Wolfrum, Rüdiger and Röben, Volker (eds.), Legitimacy in International Law (Springer, Berlin, 2008) pp. 169 188.

Tyler, Tom R., 'Legitimacy and Criminal Justice: The Benefits of SelfRegulation', 7 Ohio State Journal of Criminal Law (2009) pp. 307 $-359$.

Zahar, Alexander and Sluiter, Göran, International Criminal Law (Oxford University Press, New York, 2008) pp. 276 - 277.

\section{UN Reports and Documents}

A letter dated June 21, 1997 from the First and Second Prime Minister of Cambodia addressed to the Secretary-General, in Identical letter dated June 23, 1997 form the Secretary-General addressed to the President of the General Assembly and to the President of the Security Council, June 24, 1997, U.N. Doc. A/51/930-S/1997/488

Report of the Group of Experts for Cambodia established pursuant to General Assembly resolution 52/135, UN GAOR, 53th Sess., UN Doc.S/1999/231 \& A/53/850 (1999)

Report of the Secretary-General Pursuant to Paragraph 2 of Security Council Resolution 808 (1993), U.N. Doc. S/25704, 3 May 1993.

\section{Internet}

'Civil party lawyers debate Joint Criminal Enterprise', The Phnom Phen Post, 23 November 2008

$<$ http://www.phnompenhpost.com/index.php/2008112322811/The-

Post.blogs/civil-party-lawyers-debate-joint-criminalenterprise.html>, accessed on 13 January 2010

Mettraux, Guénaël, “Joint Criminal Enterprise” has Grown Another Tentacle!, http://www.internationallawbureau.com/blog/?p=944, accessed 20 April 2010.

Watkins, Jared L. and DeFalco, Randel C., Nullum Crimen Sine Lege, the Jurisdiction of the Extraordinary Chambers in the Courts of Cambodia \& Joint Criminal Enterprise, $<$ www.dccam.org/Tribunal/Analysis/pdf/Nullum_Crimen_JCE_\&_ The_ECCC-Watkins_\&_DeFalco.pdf $>$, accessed on 3 February 2010. 


\section{Table of Cases}

\section{Extraordinary Chambers in the Court of Cambodia}

Case of Kiang Guek Eav alias Duch, Criminal Case File No. 001/18-072007-ECCC/OCIJ (PTC 02), ECCC, Amicus Curiae concerning Criminal Case File No 001/18-07-2007-ECCC/OCIJ (PTC 02) submitted by Kai Ambos, 27 October 2008.

Case of Kiang Guek Eav alias Duch, Criminal Case File No. 001/18-072007-ECCC/OCIJ (PTC 02), ECCC, Amicus Curiae Brief of Professor Antonio Cassese and Members of the Journal of International criminal Justice on Joint Criminal Enterprise Doctrine, 27 October 2008.

Case of Kiang Guek Eav alias Duch, Criminal Case File No. 001/18-072007-ECCC/OCIJ (PTC 02), ECCC, Amicus Curiae Brief Submitted by the Centre for Human Rights and Legal Pluralism, McGill University, 27 October 2008.

Case of Kiang Guek Eav alias Duch, Criminal Case File No. 001-18-072007-ECCC, ECCC, Case Information Sheet of Kiang Guek Eav alias Duch, http://www.eccc.gov.kh/english/cabinet/files/Case_Info_DUCH_E N.pdf.

Case of Kiang Guek Eav alias Duch, Criminal Case File No. 001/18-072007-ECCC/OCIJ, ECCC, Closing Order Indicting Kaing Guek Eav alias Duch, 8 August 2008.

Case of Kiang Guek Eav alias Duch, Criminal Case File No. 001/18-072007-ECCC/OCIJ (PTC 02), ECCC, Co-Prosecutors' Appeal of the Closing Order Against Kaing Guek Eav “Duch” Dated 8 August 2008, 5 September 2008.

Case of Kiang Guek Eav alias Duch, Criminal Case File No 001-18-072007-ECCC-TC, ECCC, Co-Prosecutors' Request for the Application of Joint Criminal Enterprise, 8 June 2009.

Case of Kiang Guek Eav alias Duch, Criminal Case File No 001/18-072007-ECCC/OCIJ (PTC 02), ECCC, Decision on Appeal against Closing Order Indicting Kaing Guek Eav alias “DUCH”, 5 December 2008.

Case of Ieng Sary Case, Criminal Case File No. 002/19-09-2001-ECCC (PTC 39), Appeal Against the Order on the Application at the ECCC of the Form of Liability Known as Joint Criminal Enterprise, 3 February 2010.

Case of Ieng Sary, Criminal Case File No. 002/19-09-2007-ECCC-OCIJ (PTC 37), ECCC, Appeal Brief against the Order on the Application at the ECCC of the Form of Liability known as Joint Criminal Responsibility, 8 January 2010.

Case of Ieng Sary, Case File No. 002/19-09-2007-ECCC/OCIJ, ECCC, CoProsecutors' Supplementary Observations on Joint Criminal Enterprise, 31 December 2008. 
Case of Ieng Sary, Criminal Case File No. 002/19-09-2007-ECCC/OCIJ, ECCC, Ieng Sary's Motion against the Application at the ECCC of the Form of Liability known as Joint Criminal Enterprise, 28 July 2008.

Case of Ieng Sary Case, Criminal Case File No. 002/19-09-2001-ECCC (PTC 35), ECCC, Ieng Sary Appeal Against the OCIJ's Order on the Application at the ECCC of the Form of Liability Known as Joint Criminal Enterprise, 22 January 2010.

Case of Ieng Sary, Criminal Case File No. 002/19-09-2007-ECCC-OCIJ (PTC 38), ECCC, Ieng Thirith defence Appeal Against 'Order on the Application at the ECCC of the Form of Liability Known as Joint Criminal Enterprise' of 8 December 2009, 18 January 2010.

Case of Ieng Sary, Criminal Case File No. 002/19-09-2007-ECCC-OCIJ (PTC 38), ECCC, Decision on the Appeals Against the CoInvestigating Judges Order on Joint Criminal Enterprise (JCE), 20 May 2010

Case of Ieng Sary, Criminal Case File 002/19-09-2007-ECCC/OCIJ, ECCC, Order on the Application at the ECCC of the Form of Liability Known as Joint Criminal Enterprise, 8 December 2009.

\section{International Criminal Court}

Prosecutor v. Lubanga Dylio, 29 January 2007, ICC, Decision on the Confirmation of Charges, Case No. ICC-01/04-01/06-803

\section{International Criminal Tribunal for the Former Yugoslavia}

Prosecutor v. Blaškić, 29 July 2004, ICTY, Judgment, Case No. IT-95-14A.

Prosecutor v. Dalalic, Mucic, Delic and Landzo, 20 February 2001, ICTY, Judgment, Case No. IT-96-21-A.

Prosecutor v Duško Tadić, 14 July 1997, ICTY, Judgment, Case No. IT-941-T, ICTY.

Prosecutor v. Duško Tadić, 15 July 1999, ICTY, Case No. IT-94-1-A, ICTY, Appeal Judgment.

Prosecutor v. Enver Hadžihasanović, Mehmed Alagic and Amir Kubura, 12 November 2002, ICTY, Decision of Joint Challenge to Jurisdiction. Case No. IT-01-47-PT.

Prosecutor v. Furundžija, 20 December 1998, ICTY, Judgment, Case No. IT-96-21-T.

Prosecutor v. Ramush Haradinaj, Idriz Balaj \& Lahi Brahimaj, 3 April 2008, ICTY, Judgment, Case No. IT-04-84-T.

Prosecutor v. Milan Milutinović, Nikola Šainović \& Dragoljub Ojdanić, 21 May 2003, ICTY, Decision on Dragolijub Ojdanić's Motion Challenging Jurisdiction - Joint Criminal Enterprise, Case No. IT99-37-AR72.

Prosecutor v. Milan Milutinović, Nikola Šainović \& Dragoljub Ojdanić, 5 September 2002, ICTY, Third Amended Indictment, Case No. IT99-37-1. 
Prosecutor v. Milan Martić, 8 October 2008, ICTY, Judgment on Appeal Separate Opinion of Judge Schomburg on the Individual Criminal Responsibility of Milan Martić, Case No. IT-95-11-A.

Prosecutor v. Miroslav Kvočka, Dragoljub Prcać, Milojica Kos, Mlaño

Radić \&Zoran Žigić, 2 November 2001, ICTY, Judgment, Case

No. IT-98-30/1-T.

Prosecutor v. Miroslav Kvočka, Dragoljub Prcać, Milojica Kos, Mlaño

Radić \& Zoran Žigić, 28 February 2005, ICTY, Appeal Judgment, Case No. IT-98-30/1-A.

Prosecutor v. Ntakirutimana and Ntakirutimana, 13 December 2004, ICTR, Judgment, Case Nos. ICTR-96-10-A and ICTR-96-17-A.

Prosecutor v. Radoslav Brđanin, 26 June 2001, ICTY, Pre-Trial Decision,

Case No. IT-99-36-PT.

Prosecutor v. Radoslav Brđanin, 1 September 2004, ICTY, Judgment, Case

No. IT-98-33-T.

Prosecutor v. Radoslav Brđanin, 3 April 2007, ICTY, Appeal Judgment, Case No. IT-98-36-A.

Prosecutor v. Slobodan Milošević, Milan Milutinović, Nikola Šainović,

Dragoljub Ojdanić and Vlajko Stojijkovic, 16 October 2001, ICTY,

Second Amended Indictment, Case No. IT-99-37-PT.

Prosecutor v. Slobodan Milošević, 22 November 2001, ICTY, Amended

Indictment, Case No. IT-02-54-T.

Prosecutor v. Slobodan Milošević, 23 October 2002, ICTY, Second

Amended Indictment, Case No. IT-01-50-I.

Prosecutor v. Stakić, 22 March 2006, ICTY, Judgment, Case No. IT-97-24A.

\section{International Criminal Tribunal for Rwanda}

Prosecutor v. Edourad Karemera, Mathieu Ngirumpatse, Joseph Nzirorera and Andre Rwamakuba, 11 May 2004, ICTR, Decision on the Preliminary Motions by the Defence of Joseph Nzirorera, Edourad Karemera, Andre Rwamakuba and Mathieu Ngirumpatse Challenging Jurisdiction in Relation to Joint Criminal Enterprise, Case No. ICTR-98-44-T.

Prosecutor v. Rwamakuma, 22 October 2004, ICTR, Decision on Interlocutory Appeal Regarding Application of Joint Criminal Enterprise to the Crime of Genocide, Case No. ICTR-98-44AR72.4.

\section{Special Court for Sierra Leone}

Prosecutor v. Charles Ghankay Tayler, 16 March 2006, SCSL, Amend Indictment, Case No. SCSL-03-01-I-001.

Prosecutor v. Foday Saybana Sankoh, 3 March 2003, SCSL, Indictment, Case No. SCSL-2003-02-I-001.

Prosecutor v. Issa Hassan Sesay, Morris Kallon and Augustine Gbao, 26

October 2009, SCSL, Appeal Judgment, Case No. SCSL-04-15-A.

Prosecutor v. Johnny Paul Koroma, 3 March 2003, SCSL, Indictment, Case No. SCSL-2003-03-I. 
Prosecutor v. Moinina Fofana and Allieu Kondewa, 2 August 2007, SCSL, Judgment, Case No. SCSL-04-14-T.

Prosecutor v. Sam Bockarie, 3 March 2003, SCSL, Indictment, Case No.

SCSL-2003-04-I.

\section{Special Penals for Serious Crimes at Dili (SPSC)}

Prosecutor v. José Cardoso Fereira, 5 April 2003, SPSC, Judgment, Case No. 04/2001. 